\title{
ART-REPRENEUR: AN EXAMINATION OF THE ROLE OF ENTREPRENEURIAL SELF- IDENTIFICATION AND TECHNIQUE IN THE SUCCESS OF CREATIVE VENTURES
} by

\author{
Marissa Cristiano \\ Bachelor of Arts, Communications Studies, Concordia University 2015 \\ A Major Research Paper \\ presented to Ryerson University \\ in partial fulfillment of the \\ requirements for the degree of \\ Master of Digital Media \\ In the program of Master of Digital Media \\ Toronto, Ontario, Canada, 2016
}

CMarissa Cristiano, 2016 


\section{AUTHOR'S DECLARATION}

I hereby declare that I am the sole author of this MRP. This is a true copy of the MRP, including any required final revisions.

I authorize Ryerson University to lend this MRP to other institutions or individuals for the purpose of scholarly research

I further authorize Ryerson University to reproduce this MRP by photocopying or by other means, in total or in part, at the request of other institutions or individuals for the purpose of scholarly research.

I understand that my MRP may be made electronically available to the public. Marissa Cristiano 


\title{
$\underline{\text { ABSTRACT }}$
}

ART-REPRENEUR: AN EXAMINTATION OF THE ROLE OF ENTREPRENEURIAL SELFIDENTIFICATION AND TECHNIQUE IN THE SUCCESS OF CREATIVE VENTURES Master of Digital Media, 2016

\author{
Cristiano, Marissa \\ Master of Digital Media, Ryerson University
}

The following paper positions independent, creative producers and businesses in the creative sector as entrepreneurial. It also assesses how prior knowledge of entrepreneurship may contribute to the success of creative ventures. Through a sample of nine interviews with creative producers in the visual arts (namely digital art, multimedia production, painting, photography and new media art), this papers assesses 1) current conceptions of creative process and creative personalities 2) how entrepreneurial orientation and entrepreneurial intention has helped them achieve social or capital gain. While some artists have used bootstrapping and lean methodologies to increase their incidences of success, they were not exposed to these methodologies prior to embarking on a career in the arts. Knowledge of bootstrapping can give artists ways to maximize the social and economic resources available to them. Knowledge of lean methodology can help artists decrease the inherent risk of creating artistic products while letting them better understand their value within a marketplace. 


\section{ACKNOWLEDGEMENTS}

This paper would not be possible without the support and guidance of Dr. Miranda Campbell. She provided feedback and a wealth of knowledge about the creative industries throughout writing this paper. I would also like to thank Dr. Phil Walsh, my second reader, for providing feedback that polished and refined this paper. I would like to thank Michael Carter, Director of

Industry for the MDM program, for always offering expansive viewpoints and the potential for serendipitous interaction. Thanks to Sonya Taccone, Program Administrator for the Master of Digital Media for quelling worries, and encouraging all of our pursuits. My peers in the MDM program have never ceased to inspire me with their passion and insights. To the artists in this interview: thank you for creating and taking the time to share your knowledge with me. This paper would not have been possible without you. To my family: thanks for showing me the importance of education, discipline and curiosity. This one is for you. 


\section{DEDICATION}

To anyone that is brave enough to create something.

To anyone who has the courage to be themselves, to make mistakes, to take the road less travelled or build a road that no one has walked on before.

Keep shining, the world needs you. 


\section{TABLE OF CONTENTS}

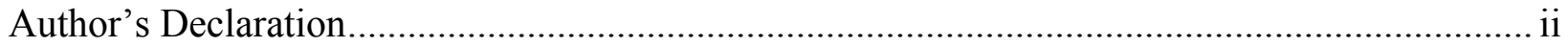

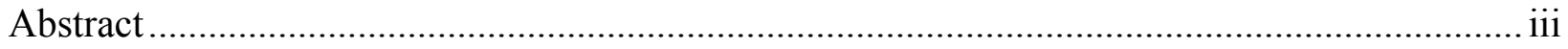

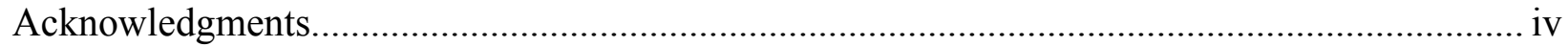

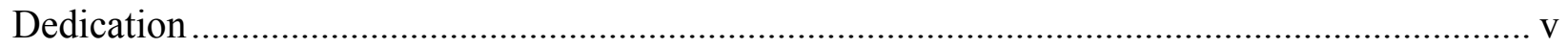

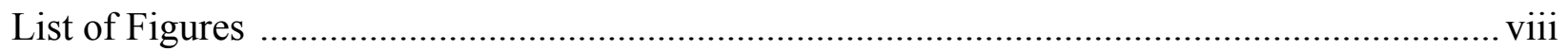

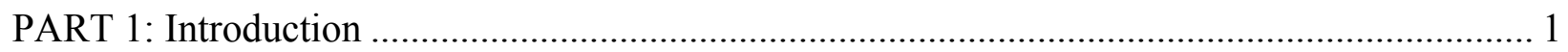

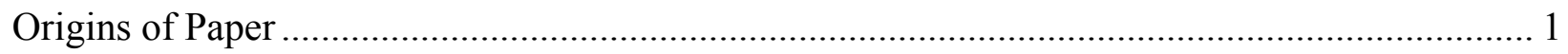

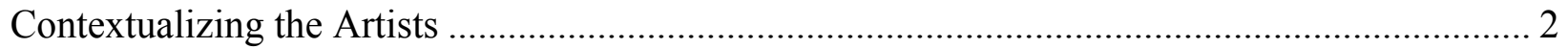

The Artist and the Entrepreneur- Common Traits \& Myhtologies ........................................... 4

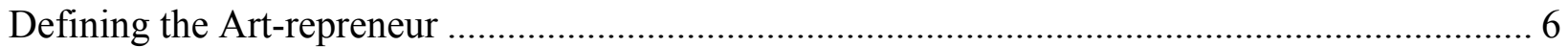

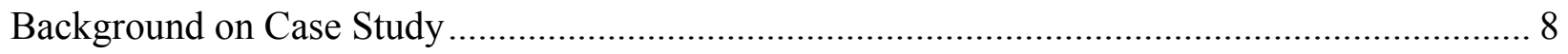

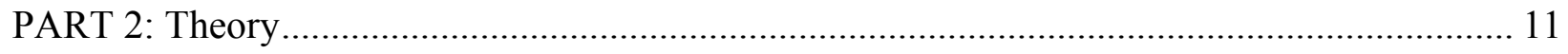

Conceptions of the Artists: From Patronage to Creative Entrepreneurs ................................... 11

The Creative Act \& The Creative Personality: What Makes Creativity Happen? ..................... 14

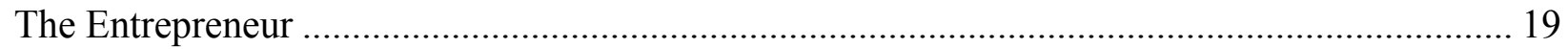

Making a Living in the Creative Industries ..................................................................... 21

What Makes the Artistic Entrepreneur Different: From Gatekeepers to Prosumers .................. 24

The Relational Perspective: The Role of the Gallery and the Artists in Profitability and

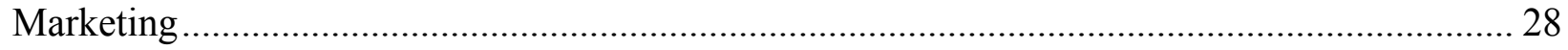

Lean Methodology: Definition and Application to the Creation of Art Objects ....................... 30

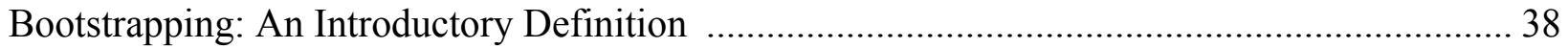

Intention Based Entrepreneurship \& Relation to the Creative Industries \& Artists ................... 39

Social Network Theory, Social Capital \& Entrepreneurship ............................................... 41

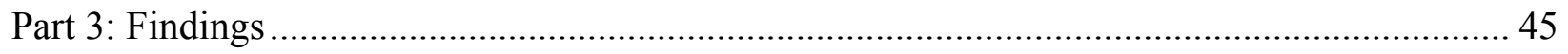

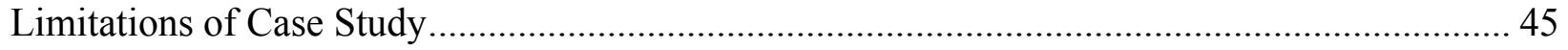

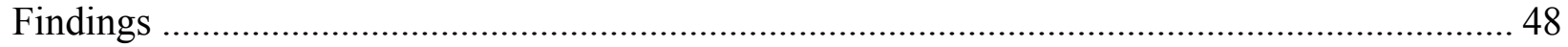

Entrepreneurial Orientation and the Entrepreneurial Role Model ........................................ 50

Lean Feedback and the Creative Process.......................................................................... 51

The Entrepreneurial Role Model and the Effect on Entrepreneurial Exposure ......................... 55 
The Entrepreneurial Personality vs. Artistic Entrepreneurial Personality ............................... 56

Common Entrepreneurial \& Bootstrapping Actions.......................................................... 58

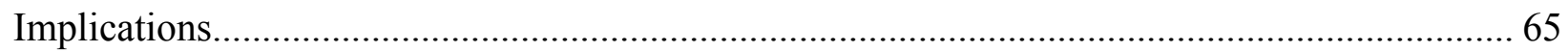

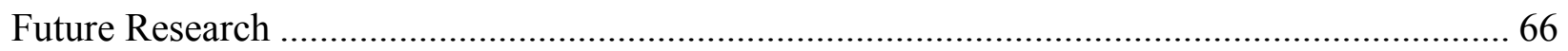

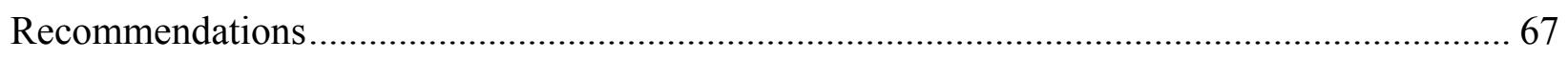

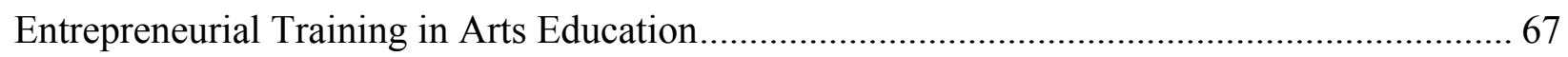

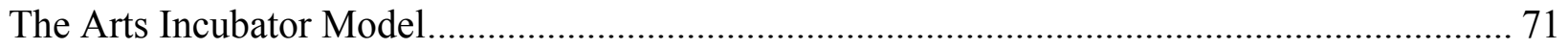

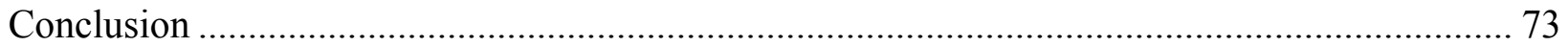

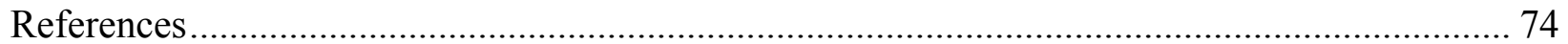




\section{LIST OF FIGURES}

Fig.1: Comparing Arts Entrepreneurship and Commercial Entrepreneurship.......................... 28

Fig. 2: The Differences Between Value Creation in Art Objects and Commercial Objects ........ 30

Fig.3:The Different Cycles in Economic Approaches to Lean and Discursive Approaches to Lean 36

Fig.4: A Visual Illustration of How Valure is Created in the Art Object .................................. 37

Fig. 5:Comparing Education,Revenue Sources, Entrepreneurial Orientation and Social Presence 


\section{PART 1: INTRODUCTION}

Origins of Paper

As an undergraduate arts and communications student, I was taught to think reflexively about who I was as an artist, how effectively my messages were communicated, and what impact my creation would have on an audience. It was assumed that this audience would exist automatically. I was never taught how to build an audience, how to maintain it, or think of who this audience would be. I went to the Master of Digital Media program to learn business practices. I sought to understand the mechanics of social and digital networks and how to leverage them to better distribute my work. Building an audience and making saleable work are things that I am currently working on in my own practice, outside the parameters of this paper.

We need to more deeply understand what it means to be a modern artist in the creative economy in order to build stronger artists and creative communities. One of my primary goals in writing this paper is to question notions of creativity that are separated from economy. I oftentimes do not accept that creative projects that are "underground" or disruptive should remain unprofitable and unseen by many. Notions of "selling out" have their roots in Romantic notions of "art for art's sake," which presume that art is a "pure" creation whose value lies in its aesthetic beauty (Gaztambide-Fernandez 242; Bourdieu 47). In this conception, the value of art is in its purity and its lack of accountability to other concerns like economics and social mores (Gaztambide-Fernandez 242). By this token, artists who would be concerned with economics would be inferior or inauthentic.

I believe there is a balance to be achieved between art and economy, where artists can find markets and make living wages, while not worrying about the watering down of artistic integrity. Likewise, business may find it rewarding to "take risks" on creativity and enlarge the cultural lexicon of what is "creative." I do not believe in the promulgation of "art" and 
"business" as separate spheres, inhabited by separate workers. Art is business and always has been. An artist should not have to choose between being seen as artistic or as business savvy. Artists are almost seven times more likely to be self-employed than workers in other industries. In 2011 in Canada, the average rate of self-employment for artists was 70.1\%, compared to $10.7 \%$ among the general population (Hill Research Strategies). This would suggest that artists need to be more entrepreneurial than the general population in order to make a living.

\section{Contextualising the Artist}

Another one of my goals in this paper is to position artists as entrepreneurs within a specialised market, and as a subject of study in entrepreneurship studies, while drawing parallels between artistic labour and entrepreneurial labour. Being creative and being entrepreneurial are not necessarily antagonistic or mutually exclusive. Pervasive mythologies, rooted in the Romantic tradition, position the "good artist" in "emotional" terms as intrinsically motivated, creating art "for art's sake" and for self-expression (Bain 28). A good artist eschews money and comfort for the freedom of "creative expression" (Bain 29). The myth of the artist-bohemian persists among artists and audiences alike (Bain 29). The common conception of the outsider artist denies economic pressures artists face, and ignores how they are increasingly "integrated" in the fabric of society as educators and curators (Adler 8). Conversely, "good entrepreneurs" are often described in "rational" terms of problem solving, opportunity assessment and calculated risk-taking over "self-expression" in their business (Howkins 51, Carol 29). However, saleability is a real concern for artists seeking to make a living, and passion / self-expression are large motivators for many entrepreneurs. This divisive view is unsustainable and diminishes the work that many artists put into building their practice. 
Some entrepreneurial artists have commoditized artistic mythologies for economic gain (Bain 29). Their hyperbolic performance of the artistic persona becomes a marketing tool that is often criticised as inauthentic or sensationalist by the art world. Damien Hirst is arguably one of the most prominent artists who is also forthright in his desire to make work that sells. Hirst is often criticized for lacking artistic integrity and depth because of his penchant to make saleable work. In her article "Damien Hirst: 'What Have I done, I’ve Created a Monster," Catherine Meyer describes Hirst as "entrepreneurial, prolific and populist [...] employing technicians to realise the bulk of his output ${ }^{1}$ " (Meyer n pag). Art critic and curator Julian Spalding has also criticized Hirst's work for its explicit commercialization. He describes Hirst's work as having "no artistic content" and therefore being "worthless works of art" (n. pag). Similarly, surrealist artist Salvador Dali also leveraged the eccentric artistic persona and controversial behavior in order to "exploit new opportunities" and "move [his] painting forward" (Fillis 138). During his time, he was criticized for his self-mythology. George Orwell called him a "dirty little scoundrel" and dismissed him as a "narcissist" (npag).

Joseph Beuys also leveraged the artist persona to create an audience for himself. Beuys was always clad in a felt suit and felt hat and took on the identity of "artist as shaman." His largest achievement is described as his ability to "invent his public, understand it and use it" (Funcke 114). However, Beuys' entrepreneurial bent and his outward search for an audience through sensationalism was criticised as deception and self-mythology instead of "real art" (Funcke 114). Despite his "loner" and outsider status, Andy Warhol "encouraged the proactive interaction of artistic creativity and entrepreneurial business practice" (Fillis 139). However,

\footnotetext{
${ }^{1}$ Online comments on the article label Hirst as a "poser" who spends too much time making money and has not developed a refined artistic sensibility.
} 
Warhol was also accused by Willem de Kooning as being a "killer of art" (Adams n.pag). It would appear that the artist's persona, saleability, and authenticity have been historically hard to reconcile in the art world. My hope is to shed light on creatives who may be entrepreneurially minded as not necessarily lacking authenticity in their work.

\section{The Artist and The Entrepreneur: Common Traits and Mythologies}

Despite the separation of artistic and entrepreneurial spheres, the rhetoric used to describe "great artists" and "great entrepreneurs" is similar. Great artists are described as outliers, whose divergent thinking patterns propel them create novel ideas and live outside of the fabric of everyday society. Sawyer defines creativity as being strongly associated with eccentricity (63). Great artists are described as intrinsically motivated by the need to self-express and create (Eikhof and Haunschild 234). Sawyer also cites the 1949 Institute for Personality Assessment and Research (IPAR) experiment from the University of California, which sought to combat stereotypes of "creative people" and their personality traits by uncovering what traits creative people actually possessed in excess. These traits, which correlate positively to creative people's success were: 1) above average intelligence 2) discernment 3) openness to experience 4) absence of repression and suppression mechanisms that control impulse imagery 5) materially comfortable childhood, but not recalled as happy 6) preference for complexity. In a similar study, Barron et al. found that flexibility, independence, tolerance of ambiguity, conscientiousness, adaptability and persistence and propensity for risk all correlated positively to artistic alignment and success. Similarly, successful entrepreneurs are described as possessing an excess of "The Big 5" personality traits: Extraversion, Agreeableness, Openness, 
Conscientiousness and Emotional Stability (Leutner et al. 59). Thus, the traits needed to be a good artist and a good entrepreneur overlap.

Both entrepreneurs and artists are mythologised as outliers, and their success is attributed to their misunderstood difference. In most biographies, successful artists are described as "loner geniuses" (Kester 87). Similarly, great entrepreneurs are described as bizarre, unable to fit the constraints of a 9-5, and obsessed by an idea they must bring to fruition. ${ }^{2}$ Rosamund Davies describes entrepreneurs as "having different perceptions of given situations" (137). In both cases, their difference allows them the ability for novel creation.

With novel creation comes a shared propensity for risk. Entrepreneurs are seen as risk takers because they sink high stakes into ventures with ambiguous futures (Ciavarella et a1. 471). Similarly, choosing to be an artist is seen as an inherently risky venture because the future is ambiguous and artists rely on their ability to create markets that do not exist (Henry 139). To minimise risk, both seek validation for their output, but in different ways. The "loner genius" artist creates art objects that are validated via being "discovered by dealers and collectors" (Kester 87), whereas the bizarre entrepreneur creates products that are validated by a buying market. The main mythologised difference between the artist and the entrepreneur is that artistic excellence can exist without economic gain, while entrepreneurial excellence is defined as accessing economic gain. While the "true artist" is expected to eschew business in favour of perfecting his or her craft, the "true entrepreneur" is expected to excel in the business world, in order to prove the value of his or her craft and passion. Despite the rhetorical separation of

\footnotetext{
${ }^{2}$ See, for example, Steve Jobs by Walter Isaacson, Founders at Work by Jessica Livingstone, and The Hard Thing about Hard Things by Ben Horowitz. The biographies of high-tech entrepreneurs highlight their eccentricity and obsessive work ethic (Chen and Kotha).
} 
commerce and creativity, entrepreneurs and artists may have more commonalities than differences.

\section{Defining the Art-repreneur}

Despite the rhetorical similarities used to describe artists and entrepreneurs, and the need for artists to be entrepreneurial, little has been done to define an art-entrepreneur and highlight the specificities of an art world context. Here, I am forwarding the term "art-repreneur" to begin to close this gap. Cultural conceptions of the artist lack an understanding of the challenges and actions of "everyday" artists seeking to make a living from their work. Artists seeking to make a living contribute to culture and the economy and are more common than "art world personalities." My term “art-repreneur" is used to describe artists who are acting as entrepreneurs in order to make a living through their artistic practice. I hope to position artists as entrepreneurs in their own right, and highlight the nuances of being an "entrepreneur" in the art world.

Eikhof and Haunschild suggest that the "antagonism between art and business" has led to a lack of scholarship defining the art-entrepreneur (234). There is still a tendency to separate the spheres of creativity and commerce and assume that commercial success will cause internal conflict for the artist (Eikhof and Haunschild 234). Conversely, in "Using Creativity to Achieve an Entrepreneurial Future for Arts Marketing," Ian Fillis and Ruth Rentschler claim that there is a natural linkage between creativity, art, marketing, and entrepreneurship. Fillis and Rentschler consider it problematic that current arts marketing paradigms are too market driven and do not embrace creativity. They propose a "creative arts marketing paradigm" which incorporates creativity and entrepreneurship into traditional marketing techniques (Fillis and Rentschler 201). 
Rentschler and Fillis argue that it this especially important to arts marketing because traditional marketing paradigms fail to account for the uniqueness of the art market.

There are more demands on artists seeking to make a living now more than ever. Artists have to concern themselves with their place in a social network and be validated at multiple social levels before they can consider financial gain. In the C.O.M.M.E.R.C.I.A.L model, Marisol d'Andre positions the artist as an entrepreneur and describes twelve roles the artist must embody in order to achieve market success. In the C.O.M.M.E.R.C.I.A.L model, the artist must be: CCREATIVE; O-OBSERVER; M-MONEY RAISER; M-MARKETER; E-ENTREPRENEUR; RREASON THEIR EXISTENCE; C-CONNECT; I-IDEAS; A-AUTHENTIC; L-LABOUR OF LOVE. This definition is important because it acknowledges the multiplicity of roles that an artist must take on in order to make a living in today's economy. It also highlights the importance of business principles, like money raising, marketing and entrepreneurship, and how these are not necessarily antagonistic to the artistic mission.

Eikhof and Haunschild note how most artists are self-employed and need to navigate two identities. The role of artist provides them with motivation for their work, while their identification as a "small firm" enables them to make a living off of their work. They argue that these conflicting cultural identities are mediated by artists seeing themselves as marginal bohemians. The possibility that artists can see themselves as inhabiting two identities that inform one another is not considered. The entrepreneurial intention and orientation of an artist is acceptable only if explained by his or her marginality for Eikhof and Haunschild.

In the following paper, I position self-employed artists as inherently entrepreneurial. I examine creative entrepreneurs or artist-entrepreneurs (Leadbeater and Oakley 9). I define an artrepreneur as a self-employed artist or creative who uses entrepreneurial savvy to make a living 
from their art work. Their market awareness, validation, or profitability does not compromise their artistic integrity, but serves to validate it. This definition serves to include both artists who see themselves as entrepreneurial and those who do not. It also aims to acknowledge how artists actually make a living in the creative economy and how entrepreneurship plays a role in this. In today's economy, artists and entrepreneurs are more alike than they are different.

\section{Background on Case Study:}

Thus, despite the cultural separation of art and business, entrepreneurs and artists are described in similar terms. Within a capitalist culture, I position artists as inherently entrepreneurial, because they rely on their own efforts to generate profit and make a living from their art. Through a sample of nine Canadian visual artists, (eight based in the GTA and one from the GTA, now based in San Francisco) I hope to discover 1) whether artists think of themselves as entrepreneurial (entrepreneurial orientation) 2) what entrepreneurial activities they may engage in, consciously or unknowingly (entrepreneurial methodology) 3) whether there is any correlation between entrepreneurial intention, entrepreneurial methodology, and ability to make a living as an artist.

I assume that entrepreneurial orientation will correlate positively towards individual commercial success for visual artists in the GTA. For the purposes of this paper, commercial success is defined as making a majority (over 51\%) of earnings from creative output. In The Independents, Leadbeater and Oakley describe a "new breed" of commercial creatives in the UK who seek commercial success as validation for their work. The study is based on creative workers in the UK, ranging from visual arts, cinema, music and performance. While a Canadian 
context is different, and I am looking more narrowly at visual artists, there may be similarities in the commercial attitudes of working artists in developed countries with free markets.

I also assume that artists who identify as entrepreneurial will be more likely to employ entrepreneurial methodologies in their production and distribution practices. Perceived entrepreneurial self-efficacy correlates positively with entrepreneurial action among commercial entrepreneurs (Kreuger et al. 415). Thus, I assume that the same relationship will exist with artists who think of themselves as entrepreneurial.

Finally, I posit that employing entrepreneurial methodology will correlate positively with commercial success. Despite the aforementioned mythology of the "bohemian" outsider artist, a growing body of literature points to how artists need to be entrepreneurial and market savvy in order to make a living today. Shein Win sees the need for the modern artist to be an "innovative entrepreneur" (2). Fillis posits the artist as a "creative marketer" (138). Timberg describes the need for artists to be "essentially entrepreneurs" (141) and Deresiewics also defines the modern artist a "creative entrepreneur." It follows that the commercially successful artists in this study may have acted entrepreneurially, and that this contributed towards their success.

There are three variances that may influence the effectiveness of an individual's entrepreneurial efforts and their profitability:

1) The Role of Race, Class, Gender and Level of Education on Earnings: There is a clear earning gap for women and people of colour in the salaried workforce. The 2011 National Household Survey and Labour Force Survey in Canada found that the earning gap between male and female artists is comparable to that of the overall workforce. The average income for female artists was $\$ 22,600$, while the average for male artists was $\$ 32,900$. On average, women earn 31\% less than men. 
The average income for visible minority artists is $\$ 23,800$. On average, visible minority artists make $40 \%$ less than the general population and $9-14 \%$ less than the general artists' population. My sample in my study is too small and too unvaried to evaluate whether this earning gap is also present.

2) The Role of the Gallery Structure:

While galleries offer more visibility and validation within artist circles, they also take a significant percentage of an artist's earnings. Galleries may help to increase the saleability of individual works, but can inhibit artists from other forms of commercial distribution like Kickstarter campaigns or selling their work directly online. There may be differences in entrepreneurial orientation and profitability between artists who are represented by a gallery and those who chose not to be.

3) The Role of Branding and Social Media in Audience Building:

Ecommerce, crowdfunding, and social media provide the means for enterprising artists to undercut the gallery structure and interact directly with their audience members (Taylor 10). However, even though online networks may allow artists to reach greater audiences, these digital business models may also make it more difficult to make a living as an artist (Taylor 10).

I am unable to account for these variances explicitly in my findings, but would still like to highlight that these factors merit further study.

\section{PART 2: THEORY}

Current research, dating from the "Creative Industries Mapping Document" by the UK Department of Culture, Media and Sport in 2001, positions artists as part of the greater "creative 
industries," and as economic drivers within the greater economy (Potts and Cunningham 233;

Banks \& Hesmondhalgh 416; Oakley 404; Flew 14). The creative industries, it follows, should be supported because they contribute to economic growth. Criticisms around this model highlight how it makes the artist subservient to economic logic (Potts et al 169; Oakley 406). The primacy of the artist and their individual initiative as well as their contributions beyond economics is rarely addressed in this model.

Conceptions of the Artist: From Patronage to Creative Entrepreneur

In order to understand current conceptions of the artist and the challenges they face, it is important to understand how artistic subjectivity has been constructed historically based on socio-economic changes. Art and commerce have always been interlinked, but their relationship has been separated and reconfigured over time.

During the Renaissance, when the patronage model was most popular, artists had very low social standing (Bain 28). They served to execute the lavish vision of the patron and to bring aesthetic beauty and grandeur to the world (Bain 28). Artists were technicians and vessels through which the elite could communicate lasting emblems of their wealth. They later developed into craftsmen. As Deresiewicz describes in "The Death of the Artist- the Birth of the Creative Entrepreneur," the artist was a master craftsman, but still a worker - hence the associations with working environments such as workshops or studios.

However, socio-economic changes brought about the shift of the artist from worker to privileged genius. The demise of mass patronage gave artists more room for self-expression, but also isolated them and removed them from the obligation of reaching their audience (Sawyer 21). Bain explains that the humanist tradition, paired with the development of the capitalist society during the industrial revolution, positioned artists as part of the intellectual elite. The abilities of 
the individual were celebrated (Bain 28). During the Romantic period, which sought innovation and novelty, artists had to retreat from the tedium of mainstream life in order to access transcendental truth and beauty that they would later communicate through their art (Bain 29). The view of the creator as isolated and independently inspired assumed that the main purpose of creation is self-expression and enlightenment. It is around this time that the stereotype of the emotionally disturbed artist took hold. In "Flow," Mihaly Czikszentmihalyi traces the myth of the troubled and disturbed artist to the biographies of Georgio Vasari in 1550, which positioned the good painters of a "new generation" as "savage and mad" (Czikszentmihalyi 56). As the societal understanding of the purpose of art-making shifted from patronage to self-expression, it became unimportant for "the creator to know who will ultimately consume his creation" (Sawyer 21). The idea of the inspired creator, detached from his or her audience, has persisted to the present day. However, it remains to be seen whether this conception is still useful for artists trying to make a living today, when social media places more importance than ever on visibility. When the artist was no longer constantly working with a patron, the patron became less visible and less influential on the creative process. Thus, the paradigmatic shift of the role of the artist also shifted the relationship/transaction between the artist and the viewer. Whereas the artist had been the servant of the buyer, placing the patron in a position of power, the buyer/viewer was now indebted to the artist. The patron was now indebted to the spiritual access artists provided through their work.

The Romantic conception of the solitary genius artist persists. Modernism created temperamental genius wonders like Jackson Pollock and Philip Rothko. North American notions of fierce individualism in capitalism also seem to uphold the myth of the solitary, divinely inspired artist in the modern imagination. However, Deresiewicz also points to the 
"professionalization" of the artist in the mid- $20^{\text {th }}$ century. The establishment of funding bodies and arts programs raised the need for professional credentials to validate working artists. The "genius artist" also needs to get a M.F.A, build a C.V, and amass credentials in order to be validated.

In the $21^{\text {st }}$ century, a growing set of artists are more entrepreneurs than professionals. What distinguishes them from their professional predecessors is their distance from the academy, the lack of stable gallerists and agents as "buffer zones" to distance these artists form market logic (Deresiewicz), and their need to understand and interpret market logic. Timberg and Deresiewicz both point to how this shift towards individual entrepreneurship is not always voluntary. Rather, it is a result of shifts in the free-market economy. As cuts have been made to grants and funding structures, and positions within the academy are harder to come by, the more viable options left for artists looking to make a living are self-employment and/or entrepreneurship (the terms are often used interchangeably). While it may be seized as an opportunity for some, it is more of a necessity and a burden to others. Social networks and online communities allow artists to reach a larger scale of people than ever before. It also places the artist closer to the consumer and the market. However, it may also increase demands on the artist to understand markets and customers and cultivate online identities. Constantly growing an online network will begin to dissolve the myth of the artist as a solitary inaccessible genius, and perhaps make it important for "the creator to know who will ultimately consume [their] creation" (Sawyer 21) again. Thus, the status of the artist has been changed in recent cultural memory from craftsman to solitary genius to professional to entrepreneur due to socio-economic changes in how art is funded. 
The Creative Act and Creative Personality: What Makes Creativity Happen?

Conceptions of the creative process and the creative personality oftentimes serve to uphold dominant cultural constructions of the artist. Research seeking to identify a creative process or a "creative personality" has oftentimes reiterated stereotypes of subversive, emotional artists, rather than successfully identifying personality traits that are prevalent among creative people. Entrepreneurs have been studied similarly. Entrepreneurial research has also sought to identify and formalise an "entrepreneurial personality."

Baron and Harrington point to two methods of evaluating creative potential. The first measure is product oriented. An individual's creative capacity is measured via his or her ability to produce creative products. The second measure seeks to identify a creative personality based on divergent thought and how this divergence scores on tests for creativity (442). Divergent thought is described as the ability to "think differently" or produce novel combinations. Kaufman explains divergence through an example. He asked a group of people, "How would the world be different if we didn't need sleep?" Answers like "we would work more" are quite typical, but an answer like "we would all love the Scissor Sisters" denotes a more divergent approach to the question. Divergent thought is strongly associated with both the creative personality and the creative process (Baron and Harrington). Similarly, the Runco Ideational Behaviour Scale sees creativity as aligned with divergent thought, problem solving, and idea generation (Runco et al. 394). Sometimes the ability to identify new patterns and express them is described as transgressive (Kozielecki, cited in Olesiewicz). Creative and divergent thinkers are distinguishable by their ability to 1) produce many ideas 2) produce many types of ideas 3) produce unusual ideas 4) develop these ideas further (Guildford 114). 
Product-oriented creativity has sometimes mystified the creative process as impenetrable. Artists are often seen as creating innovatively, without precedent. We can trace this notion back to genesis where God allegedly made the Earth: (something) out of nothing (Bain 28). Since then, the mythological view of creativity as novel creation with inexplicable roots has persisted (Sawyer 12).

More recent research has sought to systematise creativity and acknowledge its roots in previous creation. In The Creative Economy, Richard Howkins describes creativity primarily as a process that uses "ideas to generate new ideas" (4). Creativity is both the thought and the action, not necessarily the outcome of the thought and the action. Creativity combines existing concepts or ideas in a way that they have never been combined before.

Similarly, Csikzentmihalyi suggests a systems-based approach to creativity. This is a product-centred view of creativity that acknowledges the role of social actors in defining and communicating the creativity of a product in the long run. Creativity is defined as an interaction between a domain, a field, and a persona. The domain refers to a field of expertise, like art, science, or economics. The persona is the individual who creates a product. The field is defined in terms of gatekeepers, like editors, curators, or critics. The field informs the domain, and decides who is able to influence it and how. Creative output is decided in terms of the interactions between these fields (Csikszentmihalyi 1996, 1999). The systems-based view of creativity acknowledges how social structures influence can influence what we see as "creative." Creative thinkers have also been defined in terms of having greater problem-finding abilities than non-creative individuals (Getzels and Czikzentmihalyi). In Getzels and Csikzentmihalyi's “The Creative Vision: A Longitudinal Study of Problem Finding in Art," art 
students were asked to choose from 27 different objects and asked to select objects and draw them. One group of art students chose an object and spent most of their time sketching the object. The second group of art students spent more time selecting their objects, viewing them from multiple angles, and experimenting with multiple sketches of different artists. The works by the second group of artists were received as more creative by professors who judged their sketches. The group of art students who spent more time formulating visual problems in their work produced more creative works than those who did not. Five years after graduation, the subjects of the study were contacted. While members of the first group had given up making art, members of the second group were successful artists whose work was received positively by critics. Creative individuals are also said to be attracted to complexity (Gelade 215), perhaps explaining the higher level of problem-finding abilities in creative individuals.

Studies trying to identify a creative personality have treated it as an inherent personality trait and it is often (wrongly) linked to mental illness and inner turmoil (Sawyer 13). Recently, the creative personality has been defined in terms of the OCEAN model. This model defines the creative personality in terms of Openness to Experience, Conscientiousness, Extraversion, Agreeableness, and Neuroticism. The most important factor is openness to experience, which allows creatives to be open to fantasy, imagination, and a broad range of values and divergent thoughts (Sawyer 66; McCrae 1258). Some evidence has been found relating extraversion and conscientiousness with higher levels of creativity (Silvia et al. 83). Neuroticism has been negatively correlated with creativity, thus negating the mythical link between creativity and mental health (Silvia et al. 83). However, in a study on "commercial creatives," Gelade found that creatives and artists with commercial success are more prone to neuroticism (72). The same group of creatives scored higher on extraversion, and lower on conscientiousness (74-75). Ego 
formation may also be able to explain the perceived correlation between successful creatives and low conscientiousness (Mackinnon 1965). Ego strength is pronounced in individuals with high levels of creativity (Sawyer 83). High extraversion and low conscientiousness is associated with ego strength. This would suggest that commercial creatives are scoring low on conscientiousness because they do not believe that they need to work as hard as others. Other studies have suggested that creative accomplishments in the arts correlate negatively with conscientiousness (Kaufman 89; Gelade 72). In addition. King et al. found a positive link between commercial creative success and openness to experience (189). Taken in consideration with Carsrud et al.'s findings (discussed in detail below) that openness to experience correlates negatively to longterm venture success and that conscientiousness is the only quality correlating positively to venture success, this raises questions about creative entrepreneurs and the specificity of art markets. Are commercial creatives really less conscientious than commercial entrepreneurs, or is creative labour seen as less exhaustive than other forms of labour? Does the creative process not align with researcher's conceptions of conscientiousness? Whether the emotional labour, or exogenous labour (like experimentation) associated with creative processes was considered as labour at all, and thus, part of conscientiousness, was not indicated in these studies. Creative labour differs from other forms of labour, and should be measured according to different standards. Otherwise, it may be easy to de-value creative labour and confirm existing stereotypes of artists and the creative process.

One of the major problems with creativity research remains that it is not domain specific. It is possible that levels of extraversion might affect what creative endeavour an individual pursues e.g. writing over performance (Sawyer 67). Although creativity continues to be defined in relation to these five personality traits, many of the findings differ (perhaps due to their lack of 
domain-specificity) and are inconclusive (Gelade 216). Furthermore, these studies do not consider the role of self- perception in skill and identity formation. There is evidence to suggest that individuals who view themselves as creative have higher levels of creative thought (Jausi 247). Similarly, in "The Impact of Prior Entrepreneurial Exposure on Entrepreneurial IntentionCross Cultural Evidence" Mueller, Zapkau and Schwens found a positive correlation between perceived entrepreneurial self-efficacy and entrepreneurial action. People who thought of themselves as entrepreneurial were more likely to act entrepreneurially. In general, individuals who think they are more capable of accomplishing a task perform better on it that those who do not (Tierney and Farmer 1144). Perhaps this positive correlation between perceived self-efficacy and performance can be transposed to entrepreneurship. Those who see themselves as capable of making a living being self-employed are more likely to be successful at being self-employed.

While creative personality research relies heavily on perceived personality traits and the ability of personality to influence an individual's ability to create, product-based creativity research offers a more nuanced look at what differentiates a creative individual. Current personality research remains inconclusive but reinforces ideas of highly emotional and divinely inspired creatives. Product-based creativity research is preferable to developing an understanding of how creative though processes work, and how individuals can maximise their creative potential. However, research into divergent thought and the creative process by Czikzentmihalyi would also suggest that creativity is more process-oriented than inherent. More successful creative people are differentiated by their ability to formulate responses and problems in novel ways, thus negating ideas of "transcendent" creativity, and opening up the possibility for a range of people, including entrepreneurs, to be creative. 


\section{The Entrepreneur}

It is important to understand how the entrepreneur has been defined in order to identify how these definitions can easily include artists. Both entrepreneurs and artists are defined in terms of their capacity to create novel products and/or their inherent personality traits. Artists and entrepreneurs share the values of novelty, value creation, and personal motivation, despite the presence of risk. Therefore, I position artistic endeavours as similar to entrepreneurial pursuits for their purposes of this paper. The main difference between the entrepreneur and the artist seems to be that entrepreneurs create and execute novel business ideas instead of artworks.

Most definitions of entrepreneurs are similar to those used to describe artists. Productoriented definitions rely on the capacity of the entrepreneur to produce innovations.

Entrepreneurs are able to "find and use new ideas" (Brockhaus 36) and use innovation in order to distinguish themselves. This can include developing new products, new methods of doing things, discovering new markets, or new forms of organizations (Brockhaus 36). Artists may be selfemployed, but not own a business in the traditional sense. Under this definition, they would still qualify as entrepreneurs.

Joseph Schumpeter was the first economist to define entrepreneurs in terms of their human capacity to innovate. Schumpeter was also the first economist to draw a rhetorical parallel between art and economics. He likened the entrepreneur to a painter, who painted a new picture within the greater "frame" of the economy. In some literature, the entrepreneur has been referred to as highly creative and "a kind of artist" (Kozminski and Jemelniak, cited in Oleisiewicz 4). Furthermore, in the Schumpeterian model, entrepreneurs exists within capitalist culture and drive it forward, but they are said to be motivated primarily by non-capitalist means of the desire to "fight" and the joy associated with creating. Similarly, creative entrepreneurs and artists are 
described as being intrinsically motivated by the need to self-express (Eikhof and Haunschild 234; Bain 28; Leadbeater and Oakley 22).

Defining entrepreneurs and entrepreneurship still relies heavily on personality traits and preferences. Traditionally, the entrepreneur has been studied as a "special person whose qualities need to be investigated" (Gartner 22). Whether or not there are individual traits that make individuals more likely to be entrepreneurial or start businesses remains a point of contention in academic literature (Gartner 11). While personality-centred approaches to defining entrepreneurs and creatives are similar, the personality profiles of entrepreneurs and creative on these scales are different.

Entrepreneurial success is often associated with an excess of "the Big 5" personality traits: extraversion, emotional stability agreeableness, conscientiousness and openness to experience" (Ciavarella et al. 468). However, current findings by Ciavarella et al. found that the only quality that contributed to long-term venture success was conscientiousness. While openness to experience was helpful towards a venture in its early days, it ended up being damaging in the long term (Ciavarella et al. 475). Conversely, research into the creative personality found that conscientiousness correlated negatively with venture success among commercially successful creatives and openness to experience correlated positively.

Both artists and entrepreneurs are evaluated by their capacity to innovate and create novel products. Similarly, their personalities are evaluated via the same five personality factors. However, their given personality traits are different. Personality tests lack conclusive findings. As measures of "inherent" ability, they serve to culturally reinforce the idea that artists and entrepreneurs are different. Instead of looking at what actions contribute to an individual's success, they wrongly attribute an essential personality to success, thus denying individual 
agency, personal history, and the role of social networks in influencing an individual's choices and successes.

\section{Making a Living in the Creative Industries}

Now that the similarities between how artists and entrepreneurs make a living have been established, it is important to understand how the unique context of the creative industries differentiates artist entrepreneurs from other commercial entrepreneurs. The visual artists interviewed in this study are considered part of the greater creative industries. Creative industries markets are more profitable than ever in the West, but continue to pose unique challenges for creative industries entrepreneurs and workers. In Ontario, the creative industries are the fastest growing segment of the economy, and Ontario has the third largest media economy in North America, only behind California and New York (Ontario Creative Cluster Report). Between 1999 and 2007, creative economy employment doubled in Canada. Despite the economic growth of the creative industries, artists and cultural workers still make less than national average incomes. In 2011, artists made an average income of $\$ 32,770$ compared to the national average in $\$ 48,113$ in Canada (Hill Research Strategies). A majority of them are self-employed. When compared to the average earnings of the average self-employed worker, the earning gap is equally as dismal. Artists make $43 \%$ less than the average self-employed worker or entrepreneur in Toronto (D’Andrea).

It is important to acknowledge that within the creative industries self-employment and entrepreneurship is not always a voluntary choice. Many art-repreneurs may have pursued entrepreneurship because traditional "employment has become more insecure and unstable" and self-employment "is the best way for them to develop their own work" (Leadbeater and Oakley

22). They often face the challenge of sustaining new customers and businesses. The difficulties 
or circumstances that "push" artists into entrepreneurship can sometimes be ignored in favour positive cultural perceptions of entrepreneurship. Cultural policy in Britain has painted creative labour in a as a "fun" and flexible path to pursue and "work is generally presented as a key to freedom" (Banks and Hesmondhalgh 417). However, a touting of entrepreneurship as the key to freedom has glossed over the real problems that creative workers face. Creative work is “irregular, contracts tend to be short terms [...] earnings are usually slim and unequally distributed" (Banks and Hesmondhalgh 417). The instability of creative work and emphasis on self-reliance has forced many creatives into entrepreneurial behaviour like minimising operational costs, seeking contracts, performing outreach and seeking to sell themselves as a brand in order to survive (Banks and Hesmondhalgh 420; Shein Win 2). Hesmondhalgh and Banks describe this as a "process of self-commodification," where individuals sell themselves in order to improve their chances of employment (421).

Banks and O'Connor are also critical of the "utopianisation of creative labour," (366) as current conceptions of the creative industries reinforce the hegemony of economics and a capitalist system. Creative work is seen as valuable only because of its economic contribution (its potential to create jobs and revenues). With this comes the fear that culture will "become subservient to economic logic" (Banks and O'Connor 368). Banks and O'Connor explain that "a focus on the kinds of cultural production most amenable to economic rather than cultural returns" (Banks and O'Connor 368) will lead to art that is vapid, and can limit the independence of the artist and diversity of voices available. O'Connor and Banks recognize the need of "the creative industries to deal in cultural, or symbolic or expressive value" (369). The specific context in which creative products are made makes it unsuitable for creative products to "be reduced to overarching goals of growth and profiting the traditional economic model" (369). 
Existing within a capitalist system and a creative industries model places pressure on artists to be entrepreneurial in order to thrive. The visual artist must be an "innovative entrepreneur" and is expected to "fundraise and to promote their projects and to demonstrate high levels of market professionalism and market savvy" (Shein Win 2).

Seeing as a growing number of individuals contribute to the economy by being selfemployed in the arts, it is imperative to understand why they continue to earn less than the national average. In "Creative Industries and Economic Evolution," Potts concedes that 1/3 of all new fortunes in Australia are from the creative industries, and that the highest youth earners were in the creative bracket (35). Similarly, Leadbeater and Oakley highlight the market orientation of a "new generation of entrepreneurs" (12) in the creative industries in the UK. They are "self employed, freelancers and micro-businesses" who "make their own way in the market" (11). This new generation seeks validation in the commercial market, and "do not regard artistic poverty as a measure of creativity" (Leadbeater and Oakley 23). However, In "The Production and Consumption of the Arts: A View on Cultural Economics," David Throsby found that the majority of artists continue to supplement their income because they did not make a living wage from their art alone (Throsby 3). There seems to lack a "creative middle class," who is able to make "average" wages from their creative output alone. In order for the growth of creative industries to be sustainable, it will become important to have a "creative middle class" (Timberg). It is important to understand what the members of this class are doing now in order to even out the earning gap in the future.

In order to understand how artists make a living, and what effect entrepreneurial orientation has on earning potential, it is important to acknowledge different kinds of entrepreneurial subjectivity that can exist in art-repreneurs. Some artists may be "pulled" into 
entrepreneurship and creativity because of the freedom and flexibility that it affords them, while others are pushed into entrepreneurship due to circumstance. Whether the problem of earning gaps can be aided by entrepreneurship in the arts is beyond the scope and purposes of this paper. However, this paper does address the role that entrepreneurship plays in the ability of artists in this paper to make a living solely from their art. The case study provides an example of how artists make a living in Toronto today.

\section{What Makes the Artistic Entrepreneur Different?: From Gatekeepers to Pro-sumers}

Although this paper positions artists as entrepreneurs, it is important to understand how art-repreneurs differ from other commercial entrepreneurs in their motivations, in the nature of the products they create, and in the way that the art market operates. In Figure 1, I have created a comparison of arts entrepreneurs and commercial entrepreneurs.

The artistic entrepreneurs in the creative industries seems to differ from commercial entrepreneurs in their intentions. Creative industries entrepreneurs are driven by the intrinsic need to create and self-express. They value their freedom from structured employment above all else. While they seek to build wealth, they are often happy making less without structured employment (Leadbeater and Oakley 15). The entrepreneur within the creative industries can emerge from different circumstances than the entrepreneur in other industries. It is also important to note that creative industry entrepreneurs are oftentimes not "entrepreneurs" by choice, but by necessity. In order, to make a living via their creative output, they must learn how to be entrepreneurial (Timberg 85). However, in The Independents, Leadbeater and Oakley show a positive correlation between and artists viewing themselves as entrepreneurs and financial success (22). It is important to note it is never mentioned whether "viewing oneself as an 
entrepreneur" came before or after the artist's financial successes. Is their self-proclaimed entrepreneurial intention a cause or a consequence of their success?

Products in the creative industries also gain value differently than products in other commercial markets. Calvin Taylor describes two processes which distinguish the creative industries from other industries 1) the nature of the creative industries object 2) the nature of the market for creative output (182). Art objects are created by individuals, and are oftentimes valued for their uniqueness and their link to the creator over their utility. Value is created differently in creative industries markets because art objects have both economic and symbolic value. Economic value refers to the art object as a commodity or good within a market, whereas symbolic value refers to the messages or social status that an art object confers. In creative industries markets, economic value is linked to symbolic value which is culturally variable (182). That is to say, an art object's monetary worth is linked to the value it has among social circles and how it is spoken about. The creative industries are further differentiated from other markets by the presence of "gatekeepers," which are both middlemen and legitimising actors between the producers and their audiences. They help to create the symbolic value of works. Middlemen also serve to connect producers to audiences and legitimise producers to otherwise disinterested audiences (Meyer and Even 271.) Axel-Mehyer and Even describe gallery owners as having the role of "trust builder" in social networks (270). They turn the process of art into the product of art. Some other examples of this role include editors, critics, gallerists (Davies 18).

The presence of gatekeepers complicates the commercialisation of art products. Intermediaries function as translators of the abstract message of the artist and thus delineate how artistic products are understood discursively (Awdziej and Tkaczyk 841). This adds extra layers 
of interpretation and value creation within a relational model, which considers that the viewer's understanding of an artistic product completes the product (Eco cited in Axel-Meyer and Even30).

The presence of gatekeepers also complicates artistic success because dual market validation is needed, and validation in these markets have different criteria and effects (Olesiewicz 12-13). Validation from gatekeepers allows works to reach a public with a certain discursive framework that is already set up. Secondary validation from an audience and buying market furthers discursive validation and ushers in economic validation from the sale of works.

This double-market bind is only further complicated by the fact that as an artist's career progresses and becomes more profitable, their responsibilities become more sales and administration based (Olesiewicz 14). They are forced to become more extrinsic and business oriented. However, authenticity and intrinsic orientation is what correlates more positively to perception in buyers and saleability (Moulard et al. 576). This double market bind is complicated by a double perception bind, which forces the artist to be extrinsically aware and business motivated while appearing to be intrinsically motivated and naïve to markets. If they truly wish to have a profitable career, it would appear that artists are meant to play out mythologies of the artist because that is what sells.

It is also important to remember that while the arts may contribute positively to economic growth and change, they should not be valued only because they contribute monetarily to the economy. While some of the artists described in the paper are not necessarily participating in job creation, they are creating symbolic and economic value. They are what Rosamund Davies would describe as "growth oriented artistic entrepreneurs." In "Creative Industries, A New Direction," Justin O'Connor discusses how both the creative industries and arts welfare models 
inadequately describe the role of creative works and workers (390). While the arts welfare model assumes that the value of art exists outside of the market, the creative industries paradigm may lead towards a purely economic rationale for culture creation and development (89). With a purely economic rationale, it is difficult for art to be "boundary crossing" or to create riskier cultural impact (Fillis 136). In both models, culture creation is dependent on the existing markets. O'Connor suggests instead that creative industries provide new markets, called social network markets (O’Connor et al. 169). Social network markets refer to a system whereby an output or a piece of work gains value by how it is received socially and by whom ( $\mathrm{O}^{\prime} \mathrm{Connor}$ et al. 169). O'Connor gives and overview of the rise of the "prosumer,"a consumer who is active in the production of ongoing judgement of value of the works (O'Connor 179). The presence of the prosumer begins to break down the hegemony of the expert-gatekeeper and democratise social value attributed to artworks, and perhaps add complexity and variety to their cultural value.

Thus, the art market is distinct from other commercial markets because art objects have symbolic and social value, which is created and validated at two levels: within the level of the "art world" and the greater public. The presence of "gatekeepers," individuals who validate work and inscribe it with cultural importance, are a distinct group that only artist entrepreneurs must be aware of when trying to distribute artistic products. Artists seek to make a living in the art world by gaining recognition from their "field" and a greater public, but are primarily motivated by the desire to create. It is important to acknowledge that artists must gain market validation to make a living without compromising their artistic mission and integrity. 


\section{WHAT DIFFERENTIATES ART- ENTREPRENEURSHIP}

\begin{tabular}{|c|c|}
\hline Arts Entrepreneurship & Conventional Entrepreneurship \\
\hline Can be catalyzed by circumstance & Usually catalyzed by opportunity \\
\hline Entrepreneurial Intention can be absent & Entrepreneurial Intention present \\
\hline $\begin{array}{l}\text { Accrual of social capital among } \\
\text { "gatekeepers" important for reputation } \\
\text { building }\end{array}$ & $\begin{array}{l}\text { Accrual of social capital important, but in } \\
\text { less formalized way }\end{array}$ \\
\hline Dual validation/double market bind & commercial market validation \\
\hline $\begin{array}{l}\text { social value and commercial value of } \\
\text { products determined by interplay of } \\
\text { creator and market }\end{array}$ & Commercial value determined by market \\
\hline
\end{tabular}

Fig. 1- Comparing Arts Entrepreneurship and Commercial Entrepreneurship

The Relational Perspective: The Role of the Gallery and The Artist in Profitability and Meaning

The realisation that the consumer has a role in the production of a work has its roots in patronage and commissioning, where consumers' capital allowed them to direct the creative process, as well as the creative product. The importance of the consumer in feeding the arts and creating narrative and value around works is being rearticulated among complex social networks today. I have created a summary of the unique status of the art object within the relational perspective in Figure 2.

Audiences are more important than ever in shaping a cultural understanding of an art work. In "Arts Marketing Performance: An Artistic-Mission-Led Approach to Evaluation," Miranda Boorsma and Francesco Chiaravalloti highlight a few changes in the current 
gallery/museum complex that privilege the role of the viewer. These institutional changes shift the way that artists can make money both within and outside of the traditional museum complex. They explain that marketing has gone from a tool leveraged by artists to an overarching business philosophy in the art world (297). Institutions have become increasingly concerned with ticket sales and appealing to consumers (Fillis 135). According to Boorsma, this has developed alongside "a relational view of art as experience," making the consumer an essential player in “the creation and reception of arts" (297). Similar to O'Connor's prosumer, the relational perspective considers how the audience plays a role in creating the final discursive value of a work. Within the relational perspective, the work of art is only completed once the audience member has imprinted their understanding upon it. In turn, their understanding can inform narratives around the artist's greater "body of work." The artist creates the conditions for artistic experience, whereby the consumer creates the meaning of the artistic experience. The relational perspective highlight the co-creative role of the consumer, and begins to break down any Romantic notions that artists are better off not being aware of their publics. The relational perspective raises questions about why consumer feedback, or the need for profitability, is seldom discussed as an integral part of the creative process. Do most artists not think of the consumer or audience's experience when they are creating a work? Are a majority of artists unaware of or disinterested in the people who purchase and follow their work? Would an awareness of this inhibit or diminish the way that they create?

While Romanticism minimised the importance for artists to understand their end public, the relational perspective, and the active role that the consumer plays in shaping a work would suggest that artists today should be more aware of their audiences. Audiences play an active role 
in shaping an understanding of a "body of work" and an individual work's value and it could be beneficial for artists to understand how their work is received and shaped by audiences.

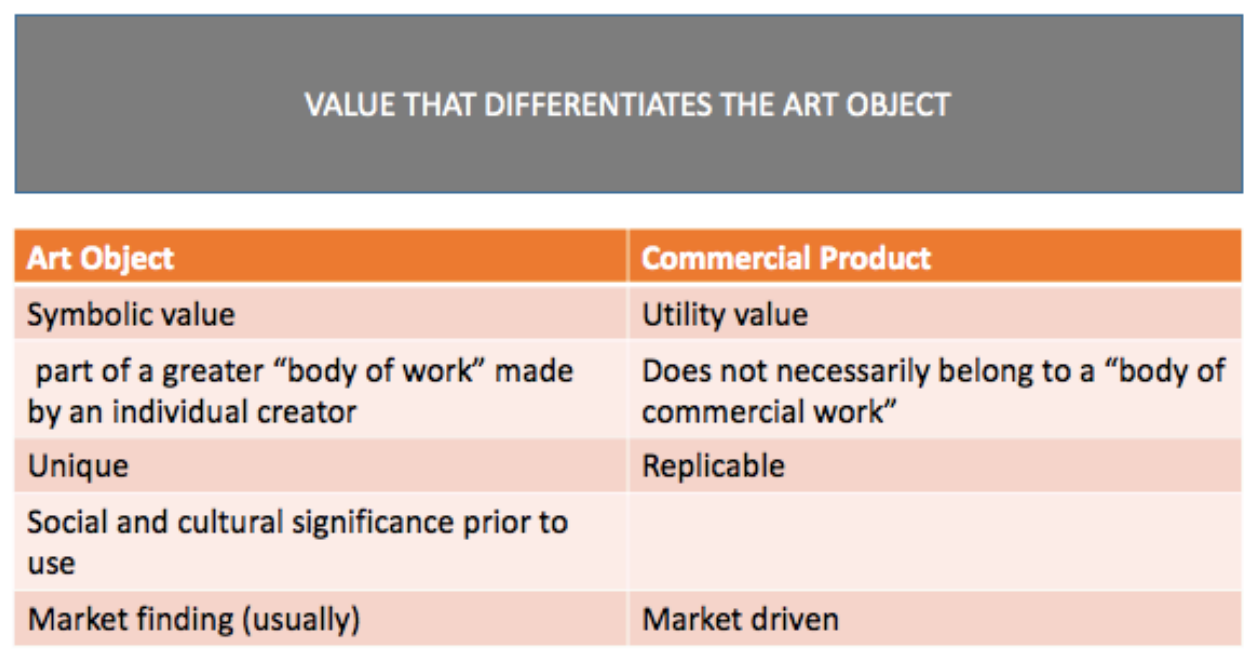

Fig. 2: The Differences Between Value Creation in Art Objects and Commercial Objects Lean Methodology: Definition and Application to the Creation of the Art Object

Lean methodology, like the relational perspective, highlights the role of an active consumer in audience creation. While the relational perspective acknowledges the role of a viewer in creating the "final work," lean methodology takes this a step further in seeking out audience feedback and integrating it in the final product (Blank n.pag). Lean thinking presupposes that greater knowledge of audience feedback leads to greater understanding and is a way for entrepreneurs to increase the incidence of success with the products they bring to market. In Figure 3, I illustrate the different ways lean can be implemented for art objects. In Figure 4, I show how value is created for an art object within the lean model. Although the art market differs from other commercial markets, the integration of lean principles, as an 
entrepreneurial tool, may help artists to get to know their audiences better and increase their incidences of success.

Lean methodology and lean thinking has its origins in lean manufacturing in the automotive industry as a way of optimizing output while minimizing waste (Ries 6). Five principles inform the lean start-up:

1) That entrepreneurs are everywhere. They are simply people who are creating "new products and services under conditions of extreme uncertainty (8). It is useful here to acknowledge that the creative product differs from the commercial product. The creative product bears the mark of the artist and his or her identity, making it belong to a greater "body of work." All creative products made by artists and our understanding of these products are interlinked and dependent upon an understanding of the "body of work." The artist's stamp or person is inextricably intertwined with the development of his or her product. Unlike other commercial products, an art object is not made solely for the practical use of an end consumer. Rather, it is also an expression of the artist and understood within the context of their previous work.

2) Entrepreneurship is management. Start-ups face extreme uncertainty, which requires special management by the entrepreneur.

3) Validated learning. Testing assumptions and learning from tests is an important part of building a sustainable business.

4) The build-measure-learn feedback loop. Entrepreneurs need to measure customer feedback in order to learn whether to change the course of their business or persevere.

5) Innovation accounting. In order to keep innovating, it is important to measure progress and set milestones. The ultimate goal of lean thinking is to learn how to build a sustainable business. Learning is a central aspect of lean thinking (Patz 3). 
For the purposes of this paper, we will be focusing on validated learning and the build-measurelearn feedback loop as tools that artists can use to better understand their customers. The idea or the assumptions that the art work is built upon needs to be validated, through testing, in order to turn it into a long-term business (Ries 9).

If we are to apply validated learning to artistic creation, it follows that artists should not assume that there are markets for their products. Before creating, the value for their work within this market should be validated, if they want to minimise risk and increase the chances of success via selling in the marketplace. Since lean methodology emerged from manufacturing, which values a product's ability to be easily reproduced in large quantities, it may be hard to reconcile with artistic output, where the value of a product lies in its uniqueness, and oftentimes, its limited circulation. In addition, creative products are often seen as creating audiences, rather than seeking audiences to serve, so there may not be an existing audience to test for creative products.

Lean methodology assumes a market-driven approach to product development. Kumar, Shear, and Kotler in "From Market Driven to Market Driving" state that "the value of being market driven is unquestioned" and "current practice dictates that success starts with careful market research, investigating the customers' needs, and developing differentiated products or services for a well-defined segment" (129). Similar market driven approaches, seeking to understand audiences, maximize their interaction with art objects, and increase ticket sales in museums have been applied to marketing the arts (Fillis 132; Boorsma 75). Market driven companies use customer insight to develop products for an existing market. In contrast, market driving companies create new markets through the radical differentness of their product (Kumar, Shear, and Kotler 130). Artistic output is often viewed as being market driving rather than market driven. As Colbert declares in "Entrepreneurship and Leadership in Marketing the Arts," 
"meeting the needs of the consumer- does not apply in high art" (31). Unlike the lean start-up which seeks "to meet consumer's needs by offering them a product they desire," the artist or the arts marketer" seeks consumers who are attracted to the product (Colbert 31). Thus, the highly innovative and personal nature of art paired with its "market driving" alignment makes it difficult to integrate the consumer directly into an iteration of the same product. The integration of lean methodology within a creative market is further complicated by the double market bind that was previously mentioned. Not only do creative products have dual value (symbolic and economic), they also face dual market validation (via "gatekeepers" and a broader consumer market). I do not mean to advocate for all artistic output to be "market-driving." Rather, I aim to highlight how there are different viewpoints on how the art object fits into a consumer market. Some artists may employ a "market driving" approach to their work, while others will employ a "market- finding" approach. Lean methodology can be employed in both approaches, but it does not assume that a purchasing market ever exists without gaining validation from that market first.

The fourth aspect of lean methodology is the build-measure-learn feedback loop. Creators and entrepreneurs are meant to "build ideas into products, measure how customers respond, and then learn whether to pivot or persevere" (Ries 9). Lean methodology is built upon the premise that constant learning and a deeper understanding of consumers and their needs can decrease the risk associated with new ventures and increase the incidences of success (Patz). The feedback loop also suggests that if a market is not responding, the creator should change their product to better fit the market. Within the context of an artistic market, Henry also hypothesizes that creative entrepreneurs may differ from general entrepreneurs because they are more personally attached to an idea. Because of this, artists who are not primarily market or sales driven are less 
likely to "pivot" or seek out market commentary and change their creations accordingly in order to maximise profitability (130).

When considering lean product development within the context of artistic creation, we must consider that with every work, two things are being built 1) the art object itself 2) our understanding of the artist's greater "body of work." Both these elements inform one another. Based on the uniqueness of the art object and its dual value and the dual-market validation it faces, I propose two approaches to implementing lean methodology in the development of art objects: an economic approach and a discursive approach. An economic approach to lean may be most useful for artists seeking to understand how to make work to better suit a market, while the discursive approach to lean may be more useful for artists seeking to understand their social significance within a market (especially within a relational arts perspective).

The economic approach assumes that "gatekeepers" and audience members comprise a universal audience. It also favours the feedback of a more general "purchasing" audience, because "economic" value precedes "symbolic" value within this model. In the economic approach, the artist builds the art object. They then place the art object before an audience to measure feedback on the physical qualities of the work. This can occur at art fairs, exhibits, or online. They then learn about what the available market likes and can adapt the work accordingly. The next time they "build" an art object, they can incorporate what they learned from audience feedback into a new piece (which becomes part of their body of work). While the artist may not be able to incorporate audience feedback into making a new iteration of the current work, they can use audience feedback to inform future iterations of a work, and consequently their "body of work." For artists working in a series or with a more mechanical and replicable process to their work, the learning process of lean start-up may be helpful in assessing 
opportunity recognition (Patz 45). It may be useful to be aware of market feedback early on in the series. This can allow market and sales driven artists to pivot accordingly throughout the series in order to increase the incidence of success and saleability of the final body of work.

To adapt the build-measure-learn feedback loop to the context of a relational art perspective, I propose a two-part building cycle. Within a relational perspective, the work is built in two ways: 1) the physical art object or experience created by the artist; and 2) the discursive creation of the art object or the experience within a greater society. The consumer may not play a direct role in the first building cycle (the physical creation of a work) because "potential evaluation decreases creativity" (Kaufman 36). However, they may play a role in its discursive creation. The artist would "build" or create the physical product (which would not be physically modified via audience feedback). However, the artist (and gatekeepers) may also "build" a story or discursive framework from which the audience understands the art object and its relation to a "body of work." The audience's perception and understanding within this discursive framework can be measured by artists and curators and be used to inform later creations or iterations of the discursive framework of the artist's "body of work."

The consumer has great steering power over innovation within lean methodology. Within the creative industries context, O'Connor's model of the prosumer and Boorsma's relational perspective both point to the emerging importance of the consumer in deciding the cultural value of an artwork over the presence of "cultural gatekeepers." These conceptions of active audience members fit well into the lean methodology model because of the loop of constant feedback that is offered by a direct interaction with an audience. The digitization of social networks opens up new possibilities for creative production. O'Connor also cautions against the commodification of these social relationships in the future, which may simply create a new tier of "gatekeeper" that 
does not declare itself, but has equally as much social influence. Lean methodology can be useful to understanding the role of art in today's world because it acknowledges the work of art as having both social and economic value. The implementation of lean depends on the artist and how market-oriented they wish to be. However, the consumer's role in lean application and the usefulness of lean methodology in the creative milieu is yet to be determined.

\begin{tabular}{|c|c|c|}
\hline Part of lean production cycle & Economic approach lean & Discursive approach to lean \\
\hline Build & Artist builds the art object & $\begin{array}{l}\text { Artist builds the art object, which is part of } \\
\text { the greater narrative of their "body of } \\
\text { work" }\end{array}$ \\
\hline \multirow[t]{2}{*}{ Build 2} & Not applicable & $\begin{array}{l}\text { "Gatekeepers" build social value of art } \\
\text { product - }\end{array}$ \\
\hline & & $\begin{array}{l}\text { Prosumers build social value of product } \\
\text { through their exegesis }\end{array}$ \\
\hline Measure & $\begin{array}{l}\text { Artist measures audience feedback } \\
\text { on the physical qualities of the work }\end{array}$ & $\begin{array}{l}\text { Artist can measure social significance of } \\
\text { product in relation to their "body of work" }\end{array}$ \\
\hline Learn & $\begin{array}{l}\text { Artist learns about what the } \\
\text { audience/market likes and makes } \\
\text { changes to the next art object } \\
\text { accordingly }\end{array}$ & $\begin{array}{l}\text { Artist can learn from the exegesis of the } \\
\text { prosumer and incorporate into the } \\
\text { discursive creation of "greater body of } \\
\text { work" }\end{array}$ \\
\hline
\end{tabular}

Fig. 3 - The Different Cycles in Economic Approaches to Lean and Discursive Approaches to

\section{$\underline{\text { Lean }}$}

Lean implementation in the creation of an art object acknowledges the role of the consumer in informing the artist's body of work. The main differentiator between both implementations of lean is the integration of two build cycles in the discursive approach: the artist building the object and audiences building narrative and interpretations of the artist's greater body of work. In both implementations, audience feedback is important, but it informs the final "body of work" in different ways. In the economic implementation it affects the body of 
work more directly, while in the discursive approach, feedback from audiences and gatekeepers create a discursive framework through which the work is discussed.

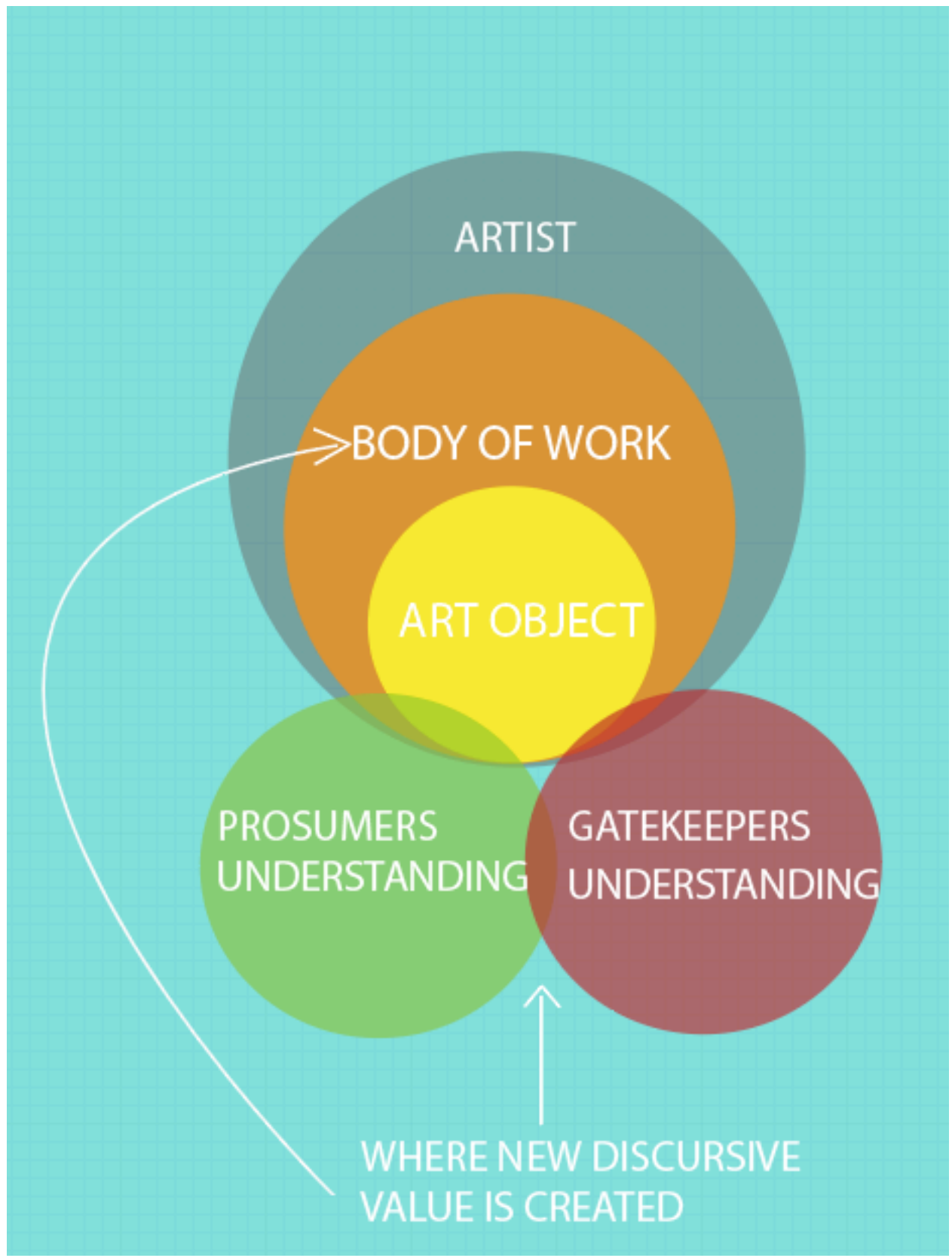

Fig. 4- A Visual Illustration of How Value is Created in the Art Object

The art object is part of a discursive "body of work" and of the identity of the "artist."

The artist creates the body of work and the art object. When prosumers and gatekeepers interact 
with an art object, their understandings affects the cultural perception of the art object, the body of work, and the "artist."

\section{Bootstrapping : An Introductory Definition}

Bootstrapping is an entrepreneurial method which has been used by entrepreneurs to create sustainable businesses in adverse conditions. Seeing as entrepreneurs and artists are described similarly, I explain how bootstrapping may be a suitable entrepreneurial method for artists. The term bootstrapping is often used in relation to small firms (Ebben and Johnson 835). Bootstrapping encompasses any methods used to reduce reliance on outside financing, "reduce overall capital requirements," and "improve cash flow" (Ebben and Johson 853). An entrepreneur pursues "opportunity regardless of the resources, or lack of resources" (Timmons 85). Bootstrapping is used when capital is scarce (Winborg and Landstrom), rather than as a first choice business methodology. Thus, bootstrapping seeks novel ways to maximise resources, even in the absence of favourable conditions. In the same way that arts-entrepreneurship sometimes emerges from necessity to make a living, bootstrapping techniques are sometimes employed due to an inability to access other resources, like exterior financing. Resource acquisition is often seen as one of the "the more important activities for successful entrepreneurs" (Needy and Van Auken 399). Needy and Van Auken also suggest that the propensity to bootstrap may be linked to specific personality traits of the entrepreneur and their preferences. Higher education lessens the constraints to starting a business and makes entrepreneurs more likely to bootstrap (Needy and Van Auken 409). Similarly, artists in Canada are more likely to pursue higher education. Nearly $44 \%$ of artists hold a bachelor's degree or higher, compared to $25 \%$ of the overall population (Hill Research Strategies). They are also $40 \%$ 
more likely to be self-employed in Canada (ibid). In turn, this would also position artists as more likely to bootstrap. Entrepreneurs with access to capital from family are more likely to bootstrap (Needy and Van Auken 400). Sharing or pooling of resources with entrepreneurs and obtaining grants are also common bootstrapping methods (Needy and Van Auken 401). All methods that maximise resource acquisition while minimising operational costs and capital expenditure are bootstrapping methods. Over the course of my study of nine artists in the GTA, I will aim to see whether artists are bootstrapping, and in what ways they are maximising their resource acquisition while minimizing their operational costs.

Intention Based Entrepreneurship and Its Relation to the Creative Industries and Artists

In order to understand how entrepreneurs and artists achieve commercial success, it is important to also understand how and why they decide to pursue their given career paths and the steps they take to become successful. I will explain how entrepreneurial intention forms in individuals and how the formation of entrepreneurial intention may pertain to artists. Entrepreneurial intention refers to the commitment of an individual to start a new business (Mueller, Zapkau, and Schwens 251). Intentions are the greatest predictors of planned behaviours and subjectivity and factor in highly to how individuals make decisions (Kreuger 412). Entrepreneurial exposure, or being exposed to entrepreneurial role models who make individuals aware of the possibility of becoming an entrepreneur, highly factor in to their entrepreneurial intention (Kreuger et al. 415). Having a positive correlation with someone having started a business is an even higher indicator of the likelihood of pursuing entrepreneurship in the future, especially when this person influences perceived attitudes of the self, like selfefficacy (Mueller et al. 260; Kreuger et al. 412). It would follow that artists who had positive 
interactions with entrepreneurship that influenced their self-efficacy would be more likely to pursue entrepreneurship in their practice. Entrepreneurial thinking and the effects of entrepreneurial orientation at the firm level have also been heavily researched (Parkman, Holloway and Sebastiao 95). However, little research looks at whether these individuals see themselves as entrepreneurial and whether entrepreneurial self-identification contributes to venture success.

According to Krueger, there are two models that explain how entrepreneurial intention can be catalysed into entrepreneurial action: Ajzen's theory of planned behaviour and Shapero's theory of the entrepreneurial event (Kreuger, Reilly, and Carsrud 413). The main difference between both theories is that the model of the entrepreneurial event assumes that entrepreneurship is motivated by a "displacement" that makes the possibility of entrepreneurship seem more feasible and desirable than ever (Kreuger et al. 416).

It is important to note that the model of entrepreneurial intention may not apply directly to artists and creators in the same way. While some artists and creators may have had positive interactions with entrepreneurial models, and high levels of perceived feasibility, their road to entrepreneurship may have been different from the "intentional" entrepreneur. While other entrepreneurs may have intended to start businesses due to their 1) own personal desire 2) desire to profit, some artistic entrepreneurs may have been pushed into entrepreneurship due to their circumstances. Instead of experiencing a "displacement" that motivates them to pursue an entrepreneurial goal, the artist entrepreneur may find themselves constantly being displaced, until entrepreneurship seems like the only viable option. Entrepreneurship may not have seemed more desirable after the entrepreneurial event, but it did seem more necessary as a result of living within a capitalist structure. Both the theory of planned behaviour and the entrepreneurial event 
only account for people who are "pulled" into entrepreneurship, motivated by the challenges of starting a new venture. They do not account for individuals who are "pushed" into entrepreneurship by necessity and who may not have an inclination toward entrepreneurship or desire to start a business (Richards, cited in Bridgstock 128). This does not deny that some artists may have had positive interactions with entrepreneurship and entrepreneurial role models. It also does not deny that some artists may be "pulled" into entrepreneurship and be motivated by starting a new venture. It simply aims to highlight that current entrepreneurial theory does not account for all the ways in which an artist may become entrepreneurial. Being "pushed" into entrepreneurship is unique to the artistic context. Artistic entrepreneurs are affected by the creative industries and future research should seek to see how entrepreneurial self-efficacy is formed in artistic entrepreneurs within this context.

\section{Social Network Theory, Social Capital, and Entrepreneurship}

Social capital plays a large role in generating potential economic capital for artists. Art markets are distinct in their need to be validated via two bodies 1) gatekeepers and 2) larger publics. Thus, social approval and referral is critical for art entrepreneurs seeking validation in art markets. Social capital is defined by Bourdieu as an aggregate of "actual or potential resources which are linked to the possession of a durable network of more or less institutionalized relationships of mutual acquaintance and recognition” (Bourdieu 86). Recognition provides members with "credential[s]" or "with the backing of collectivity" among this group. Thus, recognition within social networks is critical to self-employed artists seeking to make a living. Contracts, commissions, and clients are won through connections within a larger social network (Shortrose and Strange 48). 
Social networks have a dual function for artists. They open individuals up to entrepreneurial opportunity recognition by introducing them to a network of linked individuals with imminent potential. They also serve to strengthen the reputation and influence of the individual within those networks (Aldrich and Zimmer 13). While the theory of planned entrepreneurship sees entrepreneurs as rational actors who chose to pursue a business based on entrepreneurial intention and perceived opportunities, social network theory acknowledges the role of social factors that influence the creation of a venture. In this way, it aims to explain individuals who find themselves "falling into" entrepreneurship of self-employment or "stumble onto opportunities" rather than identifying as entrepreneurs and actively pursuing an opportunity. Aldrich and Zimmer state that "within complex networks of relationships, entrepreneurship is facilitated or constrained by linkages between aspiring entrepreneurs, resources and opportunities" (8). Similar to the theory of planned behaviour, antecedents that allow individuals to interact with entrepreneurship positively increase their chances of pursuing entrepreneurship. Within these complex networks, the authors highlight the importance of the broker role. Brokers are individuals who bridge networks by introducing individuals (otherwise removed from each other) to others with similar interests and aims (Aldrich and Zimmer 9). Diversity is important in the network because it increases the possibility of opportunity creation. For an independent agent in a network (and an entrepreneur or artist), a broker can offer greater potential opportunity by expanding their network to others that can provide social or economic value to their pursuits. Having a vast social network may increase both opportunities and resources embedded in those social networks. Individuals must demonstrate their value and build a system of trust in order to gain access to human capital and to the privilege of business opportunity. . 
When forging their place in a social network, an individual hopes to increase their social capital. In "Building an Network Theory of Social Capital," Nan Lin highlights how an investment in social capital should yield "expected returns" (30). Implicit in this theory is that social interactions carry weight and reinforce identity recognition. This is where social networks and their ability to generate social capital become important towards entrepreneurial orientation and entrepreneurial intention. An individual within a social network that reinforces an entrepreneur's identity as entrepreneurial and provides them with entrepreneurial opportunities increases their chance of identifying as entrepreneurial and being able to act entrepreneurially. Returns on social relations do not necessarily translate into economic returns (Bourdieu 86), but social capital may accrue and eventually translate into economic capital. Social returns may also include bolstering of the individual with a reputation, which elevates their significance in the network.

Networking creates the potential for economic opportunities to flourish. Certain actors in a network confer more capital and of influence than others. Thus, within the social network model, entrepreneurial success is determined by which actors (and their social weight) an entrepreneur meets within a network, rather than the strength of their prior entrepreneurial intention and exposure.

Social capital and influence plays a large role in affecting attitudes towards cultural products. Choices about production and consumption are "shaped by feedback from social networks" (Potts et al. 70). Rather than following a process of demand and supply, consumer choice operates in a complex social network. The role of other actors in a network and their influence, as well as the social value ascribed to a product, influence consumer choices (Potts 169). The novelty of cultural products carries uncertainty for purchasing consumers, and some 
actors' choices in a social network (like cultural gatekeepers) carry more influence on determining the value of cultural goods.

Social capital plays a role in generating eventual economic capital for artists. It is important to acknowledge the role of social network theory in affecting the perception and success of cultural goods. Social network theory also plays a role in entrepreneurial orientation and intention. The more actors that a person meets that confirms entrepreneurial self-efficacy in the individual, or make entrepreneurial action possible, the more likely this individual is to run a successful venture (either artistic or purely commercial).

Implications of Theoretical Understandings of Artists and Entrepreneurs

Art and business are sometimes seen as rhetorically opposed, but modern artists and entrepreneurs are similar in the actions they must take to get their work seen. However, artrepreneurs differ from conventional entrepreneurs in significant ways. Entrepreneurial intention in artist entrepreneurs may be formed as a result of circumstance. Art-repreneurs also face the challenge of dual market validation; validation by a market of "gatekeepers" and a buying market. Social networks plays an amplified role in the success of art-repreneurs. Social networks can confirm entrepreneurial subjectivity in the artist as well as provide reputation enhancement and new business opportunities for artists. Entrepreneurial methodologies like bootstrapping and lean have been helpful for commercial entrepreneurs, but need to be adapted to fit the unique context of the art market. 


\section{PART 3: FINDINGS}

Methodology

This paper is based on qualitative research that I conducted with nine visual artists. These artists included nine visual artists based out of the Greater Toronto Area. Of them one was a prior Ryerson graduate of Master of Digital Media and one is a current student of the Master of Digital Media. I selected visual artists who had a level of success or notoriety in their field (and were known to me from press). Furthermore, I selected artists who retained a majority of their earnings from their creative output. I defined this as earning $51 \%$ of their earnings or more from 1) commissions 2) contracts 3) grants 4) sales of their work 5) establishment of creative business, like a print shop, or any combination of these practices. The remaining $49 \%$ or less of their income could be gained from professional labour, odd jobs, or any other sources of earnings. Of the artists interviewed, only one (Todd Monk) has a secondary source of income, as he is employed in a visual design firm. ${ }^{3}$ The remaining respondents all earned $100 \%$ of their income from their creative output.

I obtained artist's e-mails via their websites. Artists were e-mailed and asked to meet in person, where they signed an informed consent form, and answered a set of questions. On the form, artists were asked whether or not they would like to include their name in the study. If they did not want to include their name, they could select a pseudonym of their choosing. They could also choose to remain anonymous. Interviewees' names are included in this study because their names, personas, and information are already part of the public sphere. These artists have already been written about publicly, and including their name in the study will not affect their body of

\footnotetext{
${ }^{3}$ Monk described hoping to phase out his full time job within the coming months, because he would be able to make a living off his art alone.
} 
work or reputation negatively in any way. Their names are also used as a way to provide real world, identifiable examples of artists who are able to make a living from their creative output.

Artists were asked to speak briefly about their work, what themes are present in their work, and what inspires them to create. Interviews were semi-structured, and questions were adapted and expanded based on the information that each individual artist provided in their answers. The questions broke down into five major categories. In the first section, artists were asked to describe their creative process and its relationship to their audience. In this section, the aim was to identify the steps that artists have taken to get their work seen and build an audience for their work. Another aim of this section was to assess the extent artists were in contact with their audience and employing lean methodology in the distribution and creation of their work. In the second part of the interview, artists were asked about their relationship with entrepreneurship. This section sought to establish a link between entrepreneurial selfidentification, the entrepreneurial personality, and the success of their artistic ventures. It also sought to identify what "bootstrapping" or "entrepreneurial" methods artists were using to get their work made and seen. The third part of the interview sought to identify the income sources of each artist. The last section asked about their education and its relationship to entrepreneurship. In all, interviews took 30-45 minutes and were transcribed after they occurred. Two interviews were conducted over e-mail due to geographical constraints, but both these artists are still based out of Toronto.

Qualitative research allows researchers to conduct inquiry on how "human beings understand, experience, interpret and produce the social world" (Sandelowski 893). It stresses understanding actions, and the complexity of individual human experiences over quantifying them (Jackson, Drummond, and Camara 22). Similarly, Martyn Hammersley and John L 
Campbell define qualitative research as research that identifies "how one type of thing differs from something else" (9). They also highlight how qualitative research can allow researchers to understand distinct perspectives and the complexity of experience of interviewees (Hammersley and Campbell 9-14). Qualitative research allows for more detailed understanding of a phenomena and its causality (Jackson, Drummond, and Camara 23). I chose to do qualitative research because I am seeking to see how artistic entrepreneurship is different from other forms of commercial entrepreneurship. I am also seeking to acknowledge and understand the distinct perspectives of individual artist -entrepreneurs and their individual views on 1) creativity and entrepreneurship 2) their feelings toward creation, distribution and entrepreneurship. Individual emotions and motivations are difficult to assess with quantitative methods. I thought I would get the most thorough answers through one-on-one interviews with artists, where they could answer questions privately, and outside of the framework of a questionnaire. I used a semi-structured interview style in order to collect data on interviewees. This meant that I had a pre-existing set of questions that would stimulate discussion, but allowed for interviewees to go into further detail (Cross 45). I also wanted to be able to adapt questions accordingly, and ask questions that would allow me to get more information about specific practices or experiences. It would be difficult to find patterns in behaviour, motivation, attitudes and life experience with a quantitative approach. Semi-structured interviewing allows for more flexibility with interviewees and to identify "emerging themes" in interviews (Jackson, Drummond, and Camara 25). Using a semi-structured interview style allowed me to explore specific topics with participants, while allowing them to offer their own understandings on the subject of the study (Cross 45). I was able to learn about each individual's opinion on entrepreneurship - and what informed it. It also allowed me to understand and hopefully honour their stories, inspirations and career paths in this paper. 
However, there are still limitations to a qualitative approach. The sample size for research in this study is small, which makes it hard to make generalizations about an artistic population. It also made it more difficult to scale the strength of potential responses. Rating scales may have been more objective in gaging participant's feelings towards entrepreneurship and creation than qualitative questions.

\section{Limitations of the Case Study}

The sample in this study was comprised of two women, six men and one anonymous respondent. All respondents are Caucasian and have achieved at least an undergraduate education within Canada. Four of the respondents have also pursued a post-graduate degree. Thus, the findings are inherently skewed toward the experience of white, educated artists in an urban milieu.

Artists were all told prior to their participation that the study was looking at the relationship between artistic success and entrepreneurship. It is possible that the artists who agreed to participate in the study are those that already identified as entrepreneurial, or knew that the study was seeking artists who identified as entrepreneurial. 
Findings

\begin{tabular}{|c|c|c|c|c|c|}
\hline Name & Medium & Education & $\begin{array}{l}\text { Income } \\
\text { Sources }\end{array}$ & $\begin{array}{l}\text { Entrepreneurial } \\
\text { Orientation }\end{array}$ & $\begin{array}{l}\text { Social } \\
\text { Presence }\end{array}$ \\
\hline $\begin{array}{l}\text { Alex } \\
\text { McLeod }\end{array}$ & $\begin{array}{l}\text { Digital 3-d } \\
\text { animation }\end{array}$ & $\begin{array}{l}\text { Master of } \\
\text { Digital Media, } \\
\text { Ryerson } \\
\text { University } \\
\text { B.F.A } \\
\text { Painting, } \\
\text { OCAD }\end{array}$ & $\begin{array}{l}\text { Commissio } \\
\text { ns } \\
\text { and } \\
\text { Personal } \\
\text { Sales }\end{array}$ & Yes & \begin{tabular}{|l|} 
Instagram \\
Twitter \\
3721 \\
Facebook \\
3,726
\end{tabular} \\
\hline $\begin{array}{l}\text { Justin } \\
\text { Poulsen }\end{array}$ & Photography & $\begin{array}{l}\text { Alberta } \\
\text { College of Art, } \\
\text { Photography }\end{array}$ & Commissions & Yes & \begin{tabular}{|l|} 
Instagram \\
1550 \\
Twitter- 372 \\
\end{tabular} \\
\hline $\begin{array}{l}\text { Nick } \\
\text { Wong }\end{array}$ & Photography & $\begin{array}{l}\text { Alberta } \\
\text { College of Art, } \\
\text { Photography }\end{array}$ & Commissions & Yes & \begin{tabular}{|l} 
Instagram \\
819 \\
Twitter-253
\end{tabular} \\
\hline $\begin{array}{l}\text { Anonymo } \\
\text { us }\end{array}$ & $\begin{array}{l}\text { Performance } \\
\text { Photography } \\
\& \\
\text { Videograph } \\
\text { y }\end{array}$ & $\begin{array}{l}\text { Ryerson } \\
\text { University, } \\
\text { Master of } \\
\text { Digital Media } \\
\text { And BFA } \\
\text { Studio Arts, } \\
\text { Concordia } \\
\text { University } \\
\end{array}$ & $\begin{array}{l}\text { Grants and } \\
\text { Exhibits }\end{array}$ & Yes & $\begin{array}{l}\text { Instagram } \\
281 \\
\text { Twitter -76 }\end{array}$ \\
\hline $\begin{array}{l}\text { Erin } \\
\text { Rothstein }\end{array}$ & Painting & $\begin{array}{l}\text { M.A. Art } \\
\text { History, } \\
\text { Western } \\
\text { University } \\
\text { BFA, Studio } \\
\text { Arts, } \\
\text { Concordia } \\
\text { University }\end{array}$ & $\begin{array}{l}\text { Sales of } \\
\text { Work }\end{array}$ & Yes & $\begin{array}{l}\text { Instagram } \\
1590 \\
\text { Twitter -372 }\end{array}$ \\
\hline $\begin{array}{l}\text { Todd } \\
\text { Monk }\end{array}$ & Painting & $\begin{array}{l}\text { Georgian } \\
\text { College, } \\
\text { Design Arts }\end{array}$ & $\begin{array}{l}\text { Sales of } \\
\text { Work }\end{array}$ & Yes & \begin{tabular}{|l} 
Instagram \\
3375 \\
Twitter- 587
\end{tabular} \\
\hline $\begin{array}{l}\text { Morgan } \\
\text { Jones }\end{array}$ & Photography & $\begin{array}{l}\text { University of } \\
\text { Western }\end{array}$ & $\begin{array}{l}\text { Sales of } \\
\text { Work }\end{array}$ & Yes & \begin{tabular}{|l} 
Instagram \\
397 \\
\end{tabular} \\
\hline
\end{tabular}




\begin{tabular}{|l|l|l|l|l|l|}
\hline & & $\begin{array}{l}\text { Ontario, } \\
\text { Environmental } \\
\text { Studies }\end{array}$ & & & Twitter -17 \\
\hline $\begin{array}{l}\text { Kirsten } \\
\text { McCrea }\end{array}$ & $\begin{array}{l}\text { Painting and } \\
\text { Digital } \\
\text { Illustration }\end{array}$ & $\begin{array}{l}\text { BFA, } \\
\text { Concordia } \\
\text { University, }\end{array}$ & $\begin{array}{l}\text { Commissio } \\
\text { ns }\end{array}$ & Yes & \\
\hline $\begin{array}{l}\text { Robert } \\
\text { Burden }\end{array}$ & Painting & $\begin{array}{l}\text { MFA-San } \\
\text { Francisco Art } \\
\text { Institute } \\
\text { BFA- Queen's } \\
\text { University }\end{array}$ & $\begin{array}{l}\text { Sales of } \\
\text { Work }\end{array}$ & Yes & $\begin{array}{l}\text { Instagram- } \\
4671 \\
\text { Twitter } \\
\text { (Papirmass)- } \\
3,094\end{array}$ \\
\hline
\end{tabular}

Fig. 5. Comparing Education, Revenue Sources, Entrepreneurial Orientation and Social Media Presence

Entrepreneurial Orientation and the Entrepreneurial Role Model

All the artists included in the study identified as entrepreneurial. When artists were asked if they saw themselves as entrepreneurs, they all responded yes. Entrepreneurship was not defined for the interviewees prior to the interview. Of all the artists interviewed, only three specified that they always saw themselves as entrepreneurial and business-minded. Rothstein, in particular, had a strong entrepreneurial orientation. She described herself as always having been entrepreneurial and being "very interested in business, and growing business." However, Rothstein also cited her entrepreneurial orientation as a result of her creative orientation. She described becoming increasingly entrepreneurial in her late teens, when she "wanted to make art [her] full-time profession." The anonymous respondent also described a process of becoming entrepreneurial in their late teens, when they began organising dance shows. They stated that an entrepreneurial orientation "was necessary for [them] to continue working as an artist." The comments of this respondent confirm previous theories that artist-entrepreneurs are more 
intrinsically motivated to create than non-artists (Leadbeater and Oakley 22; Fillis 16; Bridgstock 124).

This would suggest that, while trying to become artists, interviewees realised that they needed to act entrepreneurially in order to keep on making work. Perhaps the interviewees began to see themselves as entrepreneurial only after embarking on a career in the arts. Interviewees described needing be entrepreneurial in order to be artists, not necessarily wanting to be entrepreneurs. Furthermore, none of the interviewees received formal entrepreneurial or business training as part of their artistic education, even though they recognized business savvy as an integral part of becoming a successful artist. None of the artists interviewed had any current or prior knowledge of entrepreneurial methodology like bootstrapping and lean. This would suggest that creative orientation seems to proceed and inform entrepreneurial orientation in the artist and that arts entrepreneurs are motivated by a need to create and share before the desire to own and grow a business. Entrepreneurship may be nascent in the artist, prior to them pursuing a career in the arts, but seems to be "brought out" via the circumstances of being an artist within a free market. Entrepreneurial action and orientation seem to be inspired by a desire to make a living as an artist. It may be possible that returns on their entrepreneurial actions and commercial success achieved through these means could have informed the interviewees' self-identification as entrepreneurial.

\section{The Lean Feedback Loop and the Creative Process}

Out of all the artists interviewed, only three described a process that included some kind of adaption based on audience feedback. This can perhaps be explained by the fact that none of the artists in the sample described themselves as being particularly attuned to the perceptions of 
gallerists, critics, or consumers. Interestingly, these artists, McLeod, Jones and Monk, also described themselves as very sales-oriented. All three were applying lean validated learning models without having any prior knowledge of lean methodology. All three were also employing an economic rather than a discursive approach to lean methodology. More generally, interviewees described showing work in progress to "select people." Rothstein and McCrea both got feedback on works from their husbands. Burden, Poulsen, and Wong sought opinions from close friends who were also artists, but only when they were trying to work through a specific aesthetic problem.

McLeod described his early audience building and interaction on Facebook as playing a part in his motivation to create. When McLeod first started 3-D modelling, he would post images of finished or unfinished work on Facebook. Friends and acquaintances began commenting on his work, until eventually someone in his network suggested that they should "put this in a show. Let's exhibit." This interaction on Facebook, led to his first exhibit at Lonsdale gallery. He credits the process of posting his work on social media and receiving attention and feedback from potential exhibitors as reducing his operational costs. He explains that he was able "to print on demand" for the exhibition, unlike "painters [who] make work and hope to sell it." In this way, McLeod was able to reduce the risk of investing money, time, and labour into work that would not sell. Painters must buy their materials, and invest time and labour in a work, only to hope to sell one piece in the future. While McLeod still had to invest time and labour into creating a piece, his medium allowed him to create a work that was easily replicable (thus creating many potential financial return on the same amount of labour investment). The process of circulating his work over social media allowed him to secure a demand before investing in printing costs. He "didn't have an excessive inventory," because he could easily print multiples 
of a work based on the demand that was presented. In posting pieces in a certain style or centred on certain themes, he was able to gage what styles and themes were best received by audience members, curators, and gallerists. This made it easier to identify patterns in his work that were well received and apply the qualities of well-received works into the creation of future works, in the aims of strengthening his chances of positive reception and success. In displaying his work prior to fabrication, McLeod has been using a lean process of building (an artwork), measuring (its potential reception among an online audience) and learning (about the marketability of his work via online communities).

Similarly, Monk described being very attuned to the opinions of his audience because he is motivated by a desire to "make money." The first year that he participated in the Toronto Artist's Project, a contemporary art fair in Toronto where members of the public can purchase art directly from artists, he barely sold any work. The feedback that he got from the audience was that the work was too "edgy" for the Toronto Artist's project. The next year, he adapted his work based on the feedback he received and "had better sales. In "The Business of Being an Artist," Nina Pratt, a sales coach who specialises in coaching artists, highlights how art fairs and exhibits are opportunities for artists to ask questions and get to know their buying market (cited in Grant n.pag). Constantly "exhibiting artwork and eliciting reactions" is how artists can "refine the process of marketing" (ibid). Audience reactions may either prove that there is a buying public for work or (like in Monk's case) artists may learn that with a few key modifications, a buying public can be created. During the build-measure-learn cycle, Monk learned that with a few "pivots," he could expand the market for his work. The audience's feedback may not incite the artist to change the piece they have completed, but may change how the artist approaches future creations and iterations of a piece. 
Jones also described being attuned to the needs and wants of his market and characterizes himself as being very "sales-driven." He describes himself as having two tiers of products. He makes small wooden blocks that are affordably priced, and larger, more intricate pieces of wall art. When someone buys a piece of wall art, Jones describes showing them multiple iterations of the work until it was to that customer's liking. With his more affordably priced work, he will adapt subject matter based on what is selling the most at that current moment.

Most of the artists in this study did not have prior knowledge of lean methodology. McLeod, Monk, and Jones were applying principles of validated learning to the distribution of the work; however, no one was applying lean methodology directly to their creation process. There is not enough evidence to infer whether the integration of lean methodology to production or distribution practices is helpful to building and retaining audiences and selling more work. The choice to employ lean methodology in production and distribution seems to depend on what goals interviewees have with their work. Interviewees who identified as very sales oriented seemed more likely to 1) be in touch with their audience's wants and demands 2) employ some elements of lean methodology informally in their distribution. Furthermore, lean methodology seems to be most useful to artists working mechanically and in a thematically linked series. Monk, Jones, and McLeod all have a highly technical processes and the ability to reproduce works in larger quantities. For artists working on a series, with the ability to reproduce works in larger quantities, lean may help gage opportunity assessment. Testing audience reception and saleability while a series is being created may help determine if it is worth spending more time on an elaborate project.

Conversely, one interviewee described the potential of hearing audience feedback on their work, or thinking about a potential audience as limiting and potentially stifling to their 
creative process. Rothstein did not show work to a potential audience because she "likes to have agency," and found that showing unfinished work or certain pieces to a potential audience would make them "too involved." Wong made a distinction between his personal work and his commercial work. In his personal work, he would seek "do whatever [he] wants" while in his commercial work, he would show clients progress on pieces along the way. A distinction should be made here between thinking of how the audience will experience a work versus integrating audience feedback in the aims of being more saleable. Some interviewees, like the anonymous respondent, who works in interactive performance, described themselves as trying to gage how their audience will respond to their installation, but not being concerned by saleability. Overall, interviewees were more likely to show works, especially works in progress, to a network of peers for feedback on the physical qualities of the work, rather than show work to potential buyers. Robert Burden also described showing works in progress to fellow artists, as did the anonymous respondent, Poulsen, and Jones.

\section{The Entrepreneurial Role Model and the Effect of Entrepreneurial Exposure}

Of all the artists interviewed, all except one had a formal education in the arts. All of the artists interviewed declared that they had received no entrepreneurial or business training as part of their arts education. Poulsen, McCleod, Monk, McCrea and Rothstein also declared a desire for entrepreneurial training during their undergraduate studies. Most of the artists in the study described the presence of an entrepreneurial or creative role model who served as an example of how to make a living as a working artist. Poulsen described the presence of an artist entrepreneur role model when he was growing up in a small town in Alberta. He described this individual as sharing an "entrepreneurial spirit" with him and showing him the possibility of becoming a 
professional photographer. He credits this individual with showing him that his "passion could be commercially viable," when the only other career trajectories in his home town were "the military and farming."

Jones described a romantic relationship with a working artist, which allowed him to see the potential to make a living as an artist. Rothstein and Monk both considered themselves part of entrepreneurial legacies. Rothstein's grandfather owned a fabric store and heavily encouraged her to develop her artistic skills. Similarly, Monk's parents owned a business which they operated on nights and weekends that provided them with extra revenue. This showed him the possibility of working on a "professional" career and operating a business at the same time. Monk also had a second role model, an educator in his undergraduate studies who took him "under his wing" and encouraged him to continue making work.

As prior research suggests, these positive interactions with artistic and entrepreneurial role models may have contributed towards entrepreneurial intention, and made the interviewees more likely and able to act entrepreneurially. Interviewees described their undergraduate education as formative years, where they developed a social network and their subjectivity as artists. Some described developing their entrepreneurial prowess after graduation when they were trying to make a living as working artists. Some interviewees expressed that they would have liked to have entrepreneurial training during their arts education to better prepare them for careers in the arts. It is important to note that some of the role models described were art educators. This would suggest that universities and educators have the potential to influence entrepreneurial intention and action in future artists, especially if these artists do not have prior entrepreneurial role models. 
The Entrepreneurial Personality vs. the Artistic Entrepreneurial Personality

All the interviewees, except for two, identified as being introverted. However, the artists in the study also described a process of "turning on" their extraversion. Within certain contexts, like gallery showings or public art fairs, they were able to be extroverted, approach people, and talk at length about their work. It seems that most of the interviewees had to force themselves out of their natural introversion in order to reach their end goals. This self-identification as introverted (and a two level identification as being able to be extraverted) counters prior research on the creative personality, which identifies artists as unilaterally extraverted.

All of the artists in the study also displayed high levels of ambition and conscientiousness that are indicative of the entrepreneurial personality. Artists in the sample regularly set new goals for themselves, such as wanting to be represented in a certain gallery, or included in certain shows. These were their benchmarks for new levels of success and growth. All except for one described themselves as surpassing the working hours of a regular 9-5 working day. They described labouring obsessively to refine their work and acquire new skills.

However, interviewees also described an "ebb and flow" of work. Some times of the year were busier than others, forcing them to work 12 hour days, while they barely had work during other times of the year. The 2011 National Household and Labour Force Survey showed that $70 \%$ of artists worked most of the year (40 to 52 weeks), compared with $78 \%$ of the overall labour force. Whether lower working hours were due to personal choice or a lack of available work was not indicated in the study. During these times without work, many interviewees “created work" for themselves by exploring visual experiments or pursuing new projects. However, these "quiet periods" inherent to creative labour may have factored into why artists are 
often seen as scoring low on the conscientiousness factor. Artists may be traditionally deemed less conscientious because they are working less paid hours in the year than the average worker. However, working less paid hours is not necessarily a measure of conscientiousness. Someone may have failed to win enough work that month. Furthermore, conscientiousness factors may neglect to factor in the unpaid work and the emotional labour that can sometimes be associated with artistic creation. We may also consider that the high conscientiousness of the artists in this study may be a result of their entrepreneurial self-identification, seeing as entrepreneurs usually score high on conscientiousness factors. Thus, entrepreneurial artists, like the ones in this study, may be more likely to be conscientious than non-entrepreneurial artists.

\section{Common Entrepreneurial and Bootstrapping Actions}

1a) Outreach

Most of the artists in the study described pursuing media outlets, creative agencies, and gallery representation, especially at early stages in their career. Rothstein describes "cold calling" and sending press packages to galleries she wanted to be represented by. Wong and Poulsen describe outreaching via e-mail and social media to potential clients and agencies they want to produce with. McLeod recalled spending entire weeks just outreaching to design blogs he wanted to be featured in. Rothstein described cold-calling galleries and sending out press packages to galleries in her early career. Monk described cold calling and emailing galleries, as well as applying to the Toronto Artist's Project four times because he knew that once he was accepted, it would translate into positive exposure and sales. Being part of the Toronto Artist's Project "untapped" artist program is free, while booths for more developed artists are available at $\$ 2,000$. Monk qualified for the untapped program, which allowed him to gain economic capital 
(via sales) and social capital (via connections made at the fair). However, even if he did not qualify for the "untapped" program, pricing for Monk’s paintings begins at $\$ 3,700$. This meant that he would have to sell one painting to make $\$ 1,700$ and still gain social capital. The Toronto Artist Project provided an opportunity to maximise resource acquisition while reducing capital requirements.

1b) Grant-seeking

Many interviewees were aware of grants, but were discouraged from applying because of the long application processes. They also felt that getting a grant would somehow obligate them towards a political body and wanted to avoid this association. This a feeling that is echoed by Leadbeater and Oakley in The Independents, as they describe artists as being "suspicious" of public sector grants because they had "too many strings attached" (22). Rothstein stated that "I know I should apply for more grants [...] but I just haven't." Monk also felt that applying to grants would take away from time he could commit to his work and selling it. Only one interviewee, the anonymous respondent, described themselves as aggressively pursuing grants. They also described reaching out to specific grant officers when they did not receive grants, and seeking suggestions that would allow them to improve. Whereas grants can improve cash flow, and provide artists with the capital they seek to pursue their projects, they do not seem to be the first choice for resource acquisition within this study. Whether or not there is a relationship between entrepreneurial orientation and intention and the propensity to seek grants is beyond the scope of this paper, but merits further study.

1c) Leveraging Community Initiatives

Monk and Jones both described the importance of community art projects as a costeffective way for their work to be seen by a greater audience. It should be noted that Monk was 
the only respondent who had a secondary source of income as a design director. He described himself as being in a transition phase, where he could be employed by his art full time if he wanted to be. Jones was also the only respondent who did not attend a formal art school. Both were also the only respondents over the age of 40 . Monk and Jones both credit their participation in the Toronto Artists' Project and the Toronto Art Fair with enabling them to speak directly with customers and allowing their work to reach the press and a greater public. They also credit the Toronto Art Fair with leading them to eventual gallery representation.

Social capital within a larger network of gatekeepers or legitimising forces led to Monk and Jones eventually being self-sustaining as artists. Both Monk and Jones had to leverage attention and legitimacy within a greater network of the press and the public before being able to get the attention of "gatekeepers" or gallerists within an artistic milieu. Whether there is a relationship between their relative ages, their lack of formal straining as artists, and their likelihood to participate in outdoor art fairs, cannot be assessed in the scope of this paper. However, these findings may help to confirm that new power dynamics within social networks in the arts seem to be emerging. Consumers seem to have a greater role in validating the arts, and sometimes serve as the first point of validation, before art is deemed worthy of reaching the eyes of traditional "gatekeepers." In "Taking Aim," Nieves describes social media as offering "windows of unprecedented possibility," offering alternative avenues from the gallery for an "artist to achieve his or her professional goals" (218). Similarly, Keen propositions that "the Web 2.0 revolution is decimating the ranks of our cultural gatekeepers as professional critics, journalists, editors," and these gatekeepers are being "replaced by amateur bloggers, hack reviewers" (16). This may be a simplistic evaluation of how social networks and the Web have changed validation systems. Rather than eroding traditional "gatekeeper" structures, an extra 
layer of social validation seems to be needed by today's artists. Arora and Vermeylen also caution against seeing the validation of amateur opinions as a "democratization" of the artistic sphere. They explain that amateur valuations may lead to more validation levels for artists, and the "pressure to communicate to the public," rather than "more equitable" art valuation (196). Many of the artists in this study were vetted by an online or consumer audience before they were able to gain the attention and approval of traditional "gatekeepers." The "field" described by Czikszentmihalyi seems to have expanded to include a pro-consumer audience that is connected online. Instead of leveraging gallery representation first in order to build social capital within a greater network, the gallery now functions as a secondary source of validation, gained only after public attention. The interviewees' validation via gatekeepers then increased the reach of their audience and their legitimacy within a greater public.

1d) Leveraging Social Media as Social Capital

Poulsen, McLeod, and Monk spoke about a liminal moment in their careers which allowed them to leverage attention more easily. They are also the three members of the study with the highest number of followers on social channels. McLeod also described his path to gallery representation and recognition as one that was a conscious effort that occurred in person and online. McLeod has used social networks in order to build a "brand" and present an easily accessible identity for himself.

Having his immediate social network approve of and engage with the art that he was making encouraged McLeod to "share it online to a greater, out of [his] network pool." His approach was strategic. He describes a process of going "on design blogs and art blogs and fashion blogs" whose work wasn't "too different" from what he was doing. He "contacted all the blogs and found their personal e-mail addresses," with a template structure that would highlight 
the benefit he could offer them. His goal was to build momentum and credibility by being featured on different blogs. He says that he "did that for weeks. [He] didn't even make work for those weeks, [he] just seeded out information." He also cultivated a persona of an "eccentric artist" online using Twitter. He types exclusively in ALL CAPS online, likening the process of tweeting to yelling publicly into a crowd to be noticed. Some of his tweets include ponderings like "HIPSTER SINGULARITY IS REAL. THE TIME FOR THINGS LIKE COLD BREW TO REACH COSTCO ETC GETTING EXPONENTIALLY SHORTER.” McLeod also credits his presence on social media as allowing a "liminal moment" in his career to happen. He describes being featured by Kanye West's now defunct art blog as the upturn in his career. This led to two features in Canadian Art that same summer, and eventual gallery representation by Division Gallery. This process of building social capital ended up validating McLeod's presence in the art world. Even though the work he made was the same as before Kanye's endorsement, his work now carried more weight because of this social referral.

Similarly, for his 2015 promotional mailer to potential clients, Poulsen relied on shock value to leverage social capital. He sent out USB drives that were molded to resemble severed thumbs. His initiative was noticed by a number of design blogs and media outlets and ultimately led to his visibility in the art world and photography awards.

1e) Working for Free: Generating Social Capital

All artists in the study described working for free at some point. However, working for free had to offer some kind of "return" in the future, whether 1) the potential for earnings in the future; 2) access to new resources; 3) access to new social networks; 4) reputation enhancement via attention; or 5) social clout. Working for free was seen as a tool to build social capital, and expand the possibilities for paid work later on. Interviewees described working for free more 
often when they were just starting their careers, in order to enhance their reputation, but as they got busier, they no longer found time to work for free. Rothstein described having a "yes man" attitude early on in her career, but now prioritizing her paid requests over free ones. Similarly, Poulsen and Wong described accepting free work, but only when it offered them a high return in terms of social capital. Jones described "doing a lot for free in the beginning" for exposure and because he wanted to get his "work on walls." He remarked that this kind of exhibiting rarely translated to sales, and now that he is busier having to be more "careful about who and what [he] does things for." Similarly, the anonymous respondent described taking a lot of free work when they were "starting out." They still took free work when it would "open [them] up to different networks." The anonymous respondent recalled a time when a curator asked them to be part of a show for free. The curator of the show ended up being the head gallerist of the gallery and putting the artist's name forward for other shows and exhibits which eventually led to paid work and more clout in the artistic community.

\section{1f) Shared Studio Space}

Wong and Poulsen are studio-mates who pool their resources in a shared studio to cut down on operational costs. They also share their studio space with three other photographers. The anonymous artist also shared their studio space with fashion designers. Jones was also the only artist who was involved in an "art space," a co-working space shared with other artists (Walnut Studios). Whereas all the artists in this study had shared studio space in the past to cut down on costs, they no longer have to now that they are past the "start-up phase." While they indicated that they prefer to work alone in a personal studio now, many looked back on their shared studio time fondly. They described it as helpful to have a pool of other creators around, whom they could run ideas by. Jones was the only artist in the study who did not attend art 
school. He described his time at Walnut Studios as a formative experience, where he was able to ideate and convene with other artists. It was also where he met his first entrepreneurial role model. This role model showed him the possibility of being a working artist. Shared studio space was not only a way to save money for Jones. It also allowed him to build a community that he was lacking from not having attended art school.

Most of the interviewees were employing a combination of bootstrapping methods out of necessity and a lack of access to economic capital. Seeing as many of them no longer needed bootstrapping methods later in their career (i.e. no longer needed shared studio space, or having to work for free), this may suggest that there is a positive correlation between bootstrapping techniques and commercial success.

Within creative fields, it seems more important for artists to bootstrap social capital before they bootstrap economic capital. Interviewees seemed to be primarily concerned with finding a way to build their reputation and get their work seen. Once their reputation has been validated within a social network, they can begin to gain access to economic capital. All members of the study had at least a Bachelor's degree. The bootstrapping actions employed by all the artists in the sample confirm Needy and Van Auken's findings that higher education makes an entrepreneur more likely to bootstrap. Bootstrapping social capital seems to be a key differentiator between artist entrepreneurs and commercial entrepreneurs. Artists are constantly seeking ways to maximise their social capital, while minimising their expenses. Social capital accrues over time and may translate into economic capital. Artists seek ways to reach as many actors in a social network as possible, as well as meet key actors in a social network, who can open them up to economic opportunities. While social capital may not translate into economic 
capital automatically, one instance of social validation can lead to another, greater instance of social validation and can offer exponential returns as their network grows.

\section{$\underline{\text { Implications }}$}

While the participants in this study were part of a very limited and educated pool, they all identified as entrepreneurial. Some identified heavily with an entrepreneurial role model and an entrepreneurial legacy, while others described a process of becoming entrepreneurial in order to achieve their goals. It is not possible to draw a clear correlation between the strength of their individual entrepreneurial orientation and their level of success. Their self-identification as entrepreneurial may also stem from a tendency to attribute success to personal actions and motivation. They may see their success as attributable to entrepreneurial action only after their success has been achieved.

Despite the small and limited sample size, these findings might suggest that either 1) entrepreneurial orientation at the individual level correlates positively with the success of creative ventures 2 ) that individuals who are both creative and entrepreneurial are particularly concerned with achieving commercial success as artists 3 ) there is a tendency among successful individuals to attribute their success to individual action and effort.

Seeing as I did not interview artists about their entrepreneurial orientation prior to embarking on their careers, it is difficult to gage, in this study, whether they always thought of themselves as entrepreneurial, and whether this self-identification had an effect on their career trajectory. Furthermore, I did not conduct interviews with artists who did not achieve commercial success. It is possible that unsuccessful artists may also identify as entrepreneurial. There is not enough data in this study to know whether entrepreneurial orientation is a prerequisite or an indicator of success. Parkman et al. argue that involvement in the creative 
industries "closely align[s] with other characteristics of entrepreneurship, such as employing newness and novelty" (98). Entrepreneurial orientation at the level of the firm in the creative industries correlates positively with innovation capacity. It is possible that this positive correlation could be applied to the level of individual artists. In seeing themselves as entrepreneurial, interviewees may have been more likely to act entrepreneurially.

The firmest conclusion that I can draw is that individuals who are commercially successful artists in this study define themselves as entrepreneurial after they have achieved commercial success. My interviewees may serve to reinforce prior findings that higher levels of education lower the barrier of entry to becoming self-employed (Leadbeater and Oakley 21). Further Research

The findings of this study raised more questions than they answered. Further research should include a larger sample size and include a more diverse population. Further research should also seek to assess whether entrepreneurial orientation occurs before or after an artist's commercial success, and see whether there is a link between entrepreneurial orientation early on in one's career and entrepreneurial action and his or her later commercial success. It may be useful for researchers to identify patterns of conscious entrepreneurial action and which actions offer higher social or economic returns. In turn, it may also be beneficial for enterprising artists to learn these patterns early in their careers and implement them.

My sample size is too small to glean whether or not implementing lean methodology allowed interviewees greater financial or social returns than artists who do not. Further research, using a larger sample, should seek to address whether a conscious and formal implementation versus a learned an informal implementation of lean affects an artist's profitability and understanding of his or her audience. It should also seek to understand whether or not artists and 
gatekeepers are actually employing lean methodology discursively. This study also found that gatekeepers were not as prominent in the lives of artists as they seemed to be in academic literature. Future research should look at how social media and the role of prosumers is changing validation structures and discursive creation within the arts. Looking more specifically at how artists interact with their publics and how this affects their subjectivity and understanding of themselves as well as their profitability may be helpful for artists seeking to build audiences and careers. Furthermore, future research should look at artists who had more entrepreneurial exposure via education and whether or not entrepreneurial education for artists can increase their entrepreneurial intention and their incidences of success.

\section{Recommendations}

\section{Entrepreneurial Training in Arts Education}

Many writers analysing creative entrepreneurs have commented on the lack of formal or standardized entrepreneurial training as part of an arts education (Bridgstock 122; Beckman 87; Gaztambide-Fernandez 235). Despite cultural conceptions of the "starving artist," most art students expect that "their training should lead to something tangible" (Grant n.pag). Similarly, artists in this study described their education as a formative time in their aesthetic and social development. However, they conceded that their arts education was lacking in business principles, entrepreneurship, or setting expectations of what it means to be a working artist. Many expressed that the desire that their education would have prepared them more for what to expect in the future. Similarly, Beckman states that "students in the arts are eager for professional development and entrepreneurship education" (95). While some were lucky enough to have an educator who acted as a mentor, the rest of them had to "figure out" how to make a living as an artist along the way. 
Entrepreneurial education that paints entrepreneurship as positive, achievable, and appropriate to the individual increases entrepreneurial intention and entrepreneurial action. Hulsinck and Rauch surveyed entrepreneurship and supply chain management students pursuing classes in entrepreneurship. They identified that students who viewed entrepreneurship positively were more likely to start a business one year after completing their entrepreneurship courses (Hulsinck and Rauch 12). It remains to be seen whether entrepreneurial coursework that paints entrepreneurship as positive, as suitable to an artistic career and achievable, would increase 1) entrepreneurial intention 2) entrepreneurial action 3) entrepreneurial success amongst artists.

In "The Dilemmas of Startups in Creative Industries-Tensions between Artistic and Market Goals," Awdziej and Tkaczyk also found that entrepreneurs with a strong support program are more likely to be market oriented and perform well. These support networks were formed (in part) during post-secondary education, which also lowered the barrier of entry to becoming a self-employed artist. In "The Artist in Society: Understandings, Expectations and Curriculum Implications," Ruben Gaztambide-Fernandez defends the importance of an arts education in shaping the subjectivity of artists. He notes that "young artists' educational experiences shapes how they construct their artistic identities and understand their role in society" (234). Colette Henry also points to the importance of education in informing artists' range of possibilities for the future (137). She addresses how "entrepreneurship has not been greatly encouraged among artists and entrepreneurship" (137). If education, especially in light of the professionalization of the artistic career, plays such a pivotal role in forming artistic subjectivity, and entrepreneurship has become so important to artistic livelihood (Horowitz), then why are entrepreneurial viewpoints and skill sets not seen as essential tools to teach students in art schools in order for them to become great artists? If entrepreneurship is to be integrated 
into artistic education, educators should position entrepreneurship as positive and suitable to the life course of an artist (Hulsinck and Rauch 12). Artists need skills like networking, branding, and positioning as much as they need technical mastery in order to make a living.

As of the time of writing, there is no Canadian university that requires entrepreneurship classes as part of a fine arts degree. Some universities, like Ryerson University, offer a bachelor of arts in Creative Industries. The Ontario College of Art and Design also offers a minor in Entrepreneurship and Innovation, which teaches art students about business in the creative industries. Other universities, like Ohio State University, offer minors in arts entrepreneurship. However, in the rare cases that entrepreneurship is taught as part of a bachelor of fine arts program, there are elective courses outside the core curriculum of the fine arts program. Students take entrepreneurship classes within business departments (Beckman 94). While this is a step in the right direction, it is flawed in two ways. Firstly, it strengthens the rhetorical divide between arts and business, by making students take classes outside of their area of specialization. In turn, this strengthens the theoretical opposition of art and business within the individual, making them think that business is separate from art, and not part of being an artist. Artistic subjectivity and entrepreneurial subjectivity are hard to reconcile within this paradigm. Secondly, it does not tailor entrepreneurial knowledge for the sensitivities of the art market. After all, artists are entrepreneurial in different ways than commercial entrepreneurs. Bridgstock describes this as a "push and pull" entrepreneurship. While entrepreneurship students and commercial entrepreneurs are "pulled" towards entrepreneurship due to opportunity or interest, artists are oftentimes "pushed" to entrepreneurship via circumstance. A self-employed artist's motivators, aims, and challenges in "starting up" may be different from those of an entrepreneurship student. 
The nature of entrepreneurial opportunities, contexts, and processes also differs in being an artist than a small venture owner (Bridgstock 124).

Part of the problem with current art-entrepreneurship education is that there is a lack of consensus about what entrepreneurship means, especially in the context of the arts (Beckman 94). Beckman suggests developing a "context based curriculum," beginning in the first year of arts education, which would prepare young artists to understand what arts policies are, how to recognise opportunities in an art market, and allow them to experiment with different options for their careers, including managing arts organizations (98). The goal of integrating entrepreneurship directly into arts education is to empower students to see themselves as entrepreneurs and to view entrepreneurship as "transcending disciplinary bounds" and to leverage "both the artistic and individual self" (98). Knowing that art school is a formative time for a young artist's subjectivity, it would follow that positive entrepreneurial exposure and identification at this phase would translate into positive entrepreneurial intention. By increasing the number of young artists with entrepreneurship and forming entrepreneurial self-efficacy, education may play a key role in creating more entrepreneurial artists with the potential to achieve higher levels of commercial success earlier on in their careers. Equipping future creators with tools to increase the chances of future success may help them earn more than the current generation of artists.

Oakley and Leadbeater also conclude with the importance of education for young cultural entrepreneurs. In their findings, they take note of creative entrepreneurs who feel they are lacking business skills but are increasingly aware of how much they need them (40). They suggest that access to higher education that teaches the importance of flexibility, problem solving, innovation, and risk taking could be beneficial for creative entrepreneurs in addition to 
their traditional education in the arts. Colette Henry analyses the Trinity and Sunderland PACE program, which emphasises entrepreneurship. Students were taught problem-based learning and how to face adversity within an arts program. The close contact with a personal mentor fostered students' development and aided them on their entrepreneurial journey. However, she concluded that more could be done within universities to encourage the personal development of students and entrepreneurial thinking, since there stills seems to be little interplay between the creative arts in the institution and business development with organizations outside of the academy. However, in more recent years, cross-disciplinary business and art programs have been included in curriculum. London Business School has a new media business program, and the California College of Art and Design also has an MBA in Design Strategy. It will be interesting to see whether these interdisciplinary programs will be successful in fostering a business approach to the arts, while furthering an understanding of the unique context of art markets.

\section{The Arts Incubator Model}

In “Arts Incubators- A Typology," Azra Khan looks at the emerging model of art incubators. Business incubators are defined as "programs that nurture the development of entrepreneurial companies, helping them survive and grow during the start-up period, where they are most vulnerable" (Khan 170). Businesses that have been "incubated" have a 33\% higher average growth rate and higher survival rates than those who have not participated in an incubation program (Chambers and Serup 12). Carl Grodarch defines arts incubators as "an arts space that offers low-cost technical administrative \& professional assistance \&exhibition, rehearsal \&/or office space for arts organization, arts-related businesses or artists" (77). Incubators provide business networks, social networks, mentors and a "critical mass of creative 
people" at a critical stage of early business development. According to Agarwal, there is a "symbiotic relationship between individuals and their knowledge environments" (264). Thus, arts incubators, or artists working in incubators, may increase interaction with other noveltycreators, thus helping to create work that is both novel and commercially viable.

Art spaces and incubators can lower the barrier of entry for new talent. The shared and open nature of incubators can increase their potential to generate social capital, build trust networks, and provide a space for knowledge spillover and collaboration (76). As evidenced by findings in this study, social capital and trust building among social networks are an important part of winning future work for artists. While incubators may not necessary generate financial capital for an artists, they may do so indirectly via the accrual of social capital, which in a specific articulation, may translate to financial capital. Grodarch finds that arts incubators exhibited artist's work at higher rates than galleries, and that $75 \%$ of respondents at $500 \mathrm{x}$ gallery in Dallas found that their connection with an incubator led to other exhibition opportunities (Grodarch 80). However, only 33\% actually sold work in the arts incubator (81). Many universities like Ryerson University, Concordia University, and the University of Waterloo have integrated business incubators into their institution. If arts-specific incubators were integrated in arts schools and arts universities, it might help build entrepreneurial subjectivity in young artists while still in school, and increase their potential for building strong social networks.

Arts incubators should have the same goals of financial independence and community impact that business incubators have. At the same time, arts incubators should be sensitive to the unique aspects of the art market and artists. They should give artists the business tools they need to succeed. The challenge with incubation zones remains recruitment. Participating artists and founders must be already aware of their lack of business skills in order to be involved in an 
incubator and reap its benefits. While incubators help with business skills and knowledge transfer and may potentially build tighter knit and more immersive artistic communities, artists must be recruited in order to reap these potential benefits.

Furthermore, artists and arts-based businesses are often excluded from the roster of technology, financial, and biotech companies present at standard technology incubators. MaRS and the Digital Media Zone are two of Toronto's largest technology incubators. MaRS accepts applications for clean-tech, information and communications technology companies and health companies (MaRS website). Out of all the companies listed in the Digital Media Zone, none are founded by artists and no artists are present in the space (Digital Media Zone Website). Whether this is by choice (a feeling of not wanting to meld within the tech community, or as sense of not belonging to it), or by structure (incubators do not accept arts based businesses) remains to be discovered. It also remains to be seen if arts-specific incubators are beneficial towards the development of the arts and arts-based business, or if it serves to ostracise the arts from other economically viable businesses. Presently, there is very little research that is able to measure the effectiveness of arts-incubators on artistic careers and businesses, because the arts incubation model is still very new (Essig 180).

\section{$\underline{\text { Conclusion }}$}

In this study of nine artists in the GTA, it is possible to conclude that entrepreneurship plays a role in the success of commercial creatives. The extent of this role is hard to gage for the purposes of this paper, but merits further study. Furthermore, validation structures in the arts seem to be changing. Publics are playing a larger role in informing the social value of art works. Personality research remains an inconclusive way to gage entrepreneurial and artistic potential. 
Study into experience and subjectivity seem to offer more nuanced perspectives in understanding artistic entrepreneurship. At the outset of their careers, interviewees in this study were lacking formal entrepreneurial skills and knowledge, but developed these skills as their careers progressed. At the outset of an artistic career, and entrepreneurial role models played an important role in informing entrepreneurial subjectivity. Some of these role models are found in higher education, which has the potential to play a key role in informing developing artists about the possibility of entrepreneurship in the future. Artists contribute to economic and cultural development, and should be better supported in their efforts. 


\section{References}

Abbing, Hans. Why are artists Poor?: The Exceptional Economy of the Arts. Amsterdam: Amsterdam UP, 2002. Print.

Adams, James. "Can You Get Away With It? Then It Was Probably Art This Year" The Globe and Mail. 26 Dec 2013, n.pag. Web.

Adler, J.E. Artists in Offices: An Ethnography of an Academic Art Scene.

New Brunswick: Transaction Books, 1979. Print.

Agarwal, Rajshree, David Audretsch, and M.B. Sarkar. "The Process of Creative Construction: Knowledge Spillovers, Entrepreneurship, and Economic Growth." Strategic Entrepreneurship Journal.1.1(2007):106-29.Social Science Research Network.Web.20 Apr.2016.

Ajzen, Icek. "The Theory of Planned Behavior." Organizational Behavior and Human Decision Processes. 50.1(1991):179-211.Print.

Alrich, Howard and Catherine Zimmer. "Entrepreneurship Through Social Networks." California Management Review. 33:3(1985): 3-23.ResearchGate.Web. 15 Jun. 2016.

Ames, Michael \& Runco, Mark A. "Predicting Entrepreneurship From Ideation and Divergent Thinking." Creativity and Innovation Management.14:3(2005):311-315. ResearchGate.Web.07 May.2016.

Amit, Raphael, Etan Muller, and Iain Cockburn. "Opportunity Costs and Entrepreneurial Activity.” Journal of Business Venturing. 10.1:(1995) 95-100.Print.

Arora, Payal, and Filip Vermeylen. "The End of the Art Connoisseur? Experts and Knowledge Production in the Visual Arts In The Digital Age." Information, Communication \&Society.16.2(2013)194-214. Selected Works. Web. 14 July 2016.

Awdziej, Marcin and Jolanta Tkaczyk." The Dilemmas of Startups in Creative IndustriesTensions between Artistic and Market Goals." International Conference on Marketing and Consumer Behaviour, 2013, Lisbon,.edited by Pedro Fereira \& Andre Vieira, The Marketing School, 2013.

Axel-Meyer, Jorn, and Even, Ralf. "Marketing and the Fine Arts- Inventory of a Controversial Relationship. "Journal of Cultural Economics. 22(1998): 271-283. JSTOR. Web.14 July 2016.

Bain, A. "Constructing an Artistic Identity." Work, Employment and Society.19. 1(2005).25-46. Sage journals. Web. 23 March 2016. 
Blank, S. "Why The Lean Start-up Changes Everything." Harvard Business Review. 91.5(2013): 63-72.Print.

Caves, Richard E. Creative Industries: Contracts between Art and Commerce. Cambridge: Harvard UP, 2000. Print.

Banks, Mark and David Hesmondhalgh. "Looking for Work in Creative Industries Policy." International Journal of Cultural Policy, 15.4 (2009): 415-430. Print.

Baron, Robert. "Cognitive Mechanisms in Entrepreneurship: Why and When Entrepreneurs Think Differently than Other People." Journal of Business Venturing. 13.1(1998):275-294. Print.

Barron, F., and David Harrington. "Creativity, Intelligence and Personality." Annual Review of Psychology.32.1(1981):439-476.Print.

Barthes, Roland. "The Death of the Author." Image - Music - Text. Ed. and trans. Stephen Heath. New York: Hill and Wang, 1977. 142-148

Beckman, David. "'Adventuring" Arts Entrepreneurship Curricula in Higher Education: An Examination of Present Efforts, Obstacles and Best Practices." Journal of Arts Management, Law and Society 37.2(2007):87-112. Print.

Benjamin, Walter. Illuminations. New York: Schocken Books, 1969. Print.

Boorsma, Miranda and Franceso Chiaravalloti. "Arts Marketing Performance: An Artistic-Mission-Led Approach to Evaluation." The Journal of Arts Management, Law and Society. 40(2010):297-315. Taylor and Francis. Web. 23 March 2016.

Boorsma, Miranda. "A Strategic Logic for Arts Marketing: Integration Customer Value for Artistic Objectives." International Journal of Cultural Policy. 12.1(2006):73-92. Taylor and Francis.Web. 23 March 2016.

Bourdieu, Pierre. "The Forms of Capital." Handbook of Theory and Research for Sociology and Education, edited by J Richardson, Greenwood, 1986, pp.44-48. Print.

Brin Bookers, Brenda, Michael Fern and Leslie J Francis. "The Personality Profile of Artists.” The Irish Journal of Psychology.22.3( 2001):277-281. Print.

Bridgstock, Ruth S. \& Lauren Carr. "Creative Entrepreneurship Education for Graduate Employability in the Creative Arts." The CALTN Papers : The Refereed Proceedings of the Creative Arts Learning and Teaching Network Symposium,2013,Tasmania edited by Jonathan Holmes, Tasmanian College of the Arts,2013. 
Bridgstock, Ruth. "Not a Dirty Word: Arts Entrepreneurship and Higher Education." Arts \& Humanities in Higher Education. 12.1(2012):122-137.Print.

Brockhaus, Robert H. “Entrepreneurial Folklore.” Journal of Small Business Management. 25.3 (1987).1-6. ProQuest.Web. 14 July 2016.

Brockhaus, Robert and Horwitz, P.S. "The Psychology of the Entrepreneur." The Art and Science of Entrepreneurship, edited by D.L. Sexton \& R.W. Smilor, Cambridge, 1986, pp.25-48.

Caust, Jo. "Putting the Arts Back into Arts Policy Making: How arts policy has been captured by Economists and Marketers." The International Journal of Cultural Policy.9.1(2003)51-63. Print.

Caves, Richard E. "Contracts Between Art and Commerce." The Journal of Economic Perspectives.17.2(2003)73-84. American Economic Association. Web. 12 February 2016.

Carsrud, A., et al. "Entrepreneurship Research In Quest of a Paradigm" in The Art and Science of Entrepreneurship. Cambridge: Ballinger. Print.

Carsrud, Aland, Michael D. Reilly, and Norris F. Krueger. "Competing models of Entrepreneurial Intention." Journal of Business Venturing. 15. (2000): 411-432.

Elsevier.Web. 23 January 2016.

Ciavarella et al. "The Big Five and Venture Survival: Is There a Linkage." Journal of Business Venturing, 19.1(2004): 465-483. Print.

Chambers, Majbritt and Erik Knud Serup. Incubators for Creative Entrepreneurs. Vejle: Innovation and Environment Regions of Europe Sharing Solutions,2011.

Chaston \& Sadler Smith. "Entrepreneurial Cognition, Entrepreneurial Orientation and Firm Capability in the Creative Industries.” British Journal of Management. 23.1 (2012): 415-432. Wiley Publications. Web. 07 May 2016.

Chen, Xiao-Ping \& Kotha Xin. "Think Passionate." Stanford Social Innovation Review.7.3(2009)11-12. Print.

Colbert, F. Marketing Culture and The Arts. Montreal, Quebec: HEC Press, 2001. Print.

Coleman, James. "Social Capital in the Creation of Human Capital" The American Journal of Sociology.94(1988):95-120. Print.

Cook, Roger. "Andy Warhol, Capitalism, Culture, and Camp." Space \&Culture. 6.1 (2003): 66-76. Print. 
Cunningham, Stuart. What Price a Creative Economy? New South Wales: Strawberry Hills Currency House, 2006. Print.

Csikszentmihalyi, Mihaly. Creativity: Flow and the Psychology of Discovery and Invention. New York: Harper Collins Publishers, 1996. Print.

Cross, Wiilliam E. and Anne Galletta. Mastering the Semi-Structured Interview and Beyond: From Research Design to Analysis and Publication. New York: NYU Press, 2013. Print.

Davies, Rosamund and Gauti Sigthorsson. Introducing the Creative Industries: From Theory to Practice. Sage: London, 2013. Print.

D'andre, Marisol. The Role of the Artist in Toronto's Creative Economy. Martin Prosperity Institute: Toronto, 2011.Print.

Davidsson, Per. "Determinants of Entrepreneurial Intentions." RENT IX, Piacenza, Italy. 23 Nov, 1995,E-Prints, 1995.

Deresiewicz, William. "The Death of the Artist and the Birth of the Creative Entrepreneur." The Atlantic. N.pag. January/February 2015. Web.

Desmarais, Christian. "10 Extreme Bootstrapping Ideas.” Inc.com. n.pag. 13 June 2013. Web.

Digital Media Zone Website. Ryerson University. http://dmz.ryerson.ca/. Accessed 04 August 2016.

Drucker, Peter F. Innovation and Entrepreneurship: Practice and Principles. New York: Harper \& Row, 1985. Print.

Dvir, Dov. Arik Sadeh and Ayala Malach-Pines. "The Fit Between Entrepreneur's Personalities and the Profile of the Ventures they Manage and Business Success: An Exploratory Study." Journal of High Technology Management Research. 21(2010): 4351. Print.

Ebben, Jay and Alec Johnson. "Bootstrapping in Small Firms an Empirical Analysis of Change over Time." Journal of Business Venturing. 21 (2006): 851-865. Print.

Eikhof, Doris Ruth \& Haunschild, Axel. "Lifestyle Meets Market: Bohemian Entrepreneurs in Creative Industries." Creativity and Innovation Management. 15.3(2006):234-241. Wiley Online. Web.14 June 2016.

Essig, Linda. "Arts Incubators: A Typology." The Journal of Arts Management, Law, and Society 44.3 (2014): 169-80. Taylor and Francis. Web. 23 January 2016. 
Fillis, Ian \& Ruth Rentschler. "Using Creativity to achieve and Entrepreneurial Future for Arts Marketing." International Journal of Nonprofit and Voluntary Sector Marketing. 10(2005).275-286. Print.

Fillis, Ian. "The Evolution and Development of Arts Marketing Research." Arts Marketing: An International Journal.1(2011).11-25. Emerald Insight. Web. 04 March 2016.

Fillis, Ian. "Creative Marketing and the Art Organisation: What Can the Artist Offer?" International Journal of Non-profit and Voluntary Sector Marketing. 7.2 (2002):131-145. Wiley Online. Web. 04 March 2016.

Flew, Terry. The Creative Industries: Culture and Policy. Los Angeles, CA: SAGE, 2012. Print.

Florida, Richard. The Rise of The Creative Class: How It's Transforming Work, Leisure, Community and Everyday Life. New York: Basic Books, 2002. Print.

Bourdieu, Pierre. "The Forms of Capital." Handbook of Theory and Research for Sociology and Education, edited by J Richardson, Greenwood, 1986, pp.44-48. Print.

Foucault, Michel. "What is an Author?” Twentieth-Century Literary Theory, edited by Vassilis Lambropoulos and David Neal Miller, Albany State UP of NY, 1987. pp. 12442. Print.

Funcke, Bettina. "Joseph Beuys: Charlatanism as Media Strategy." Pop or Populus: Art between High and Low, trans.Warren Niesluchowski. Cologne:Verlag der Buchhandlung Walther König, 2008. Print.

Gartner, William B. “'Who Is an Entrepreneur?' Is the Wrong Question.” American Journal of Small Business. 12.4. (1989):11-32. Print.

Gaztambide-Fernandez, Ruben A. "The Artist in Society: Understandings, Expectations, and Curriculum Implications." Curriculum Inquiry. 38.3(2008).233-265. Print.

Gelade, G.A. "Creativity in Conflict: The Personality of the Commercial Creative” Journal of Genetic Psychology. 158(1997):67-78. Print.

Gelade, G.A. "Creative Style, Personality, and Artistic Endeavor” Genetic, Social, and General Psychology Monographs. 128.3 (2002): 213-234. Print.

Gerl, Ellen, Joy Miller- Upton, and Meredith Erlewine. Incubating the Arts: Establishing a Program to Help Artists and Arts Organizations Become Viable Businesses. Athens, $\mathrm{OH}$ : National Business Incubation Association, 2000. Print. 
Getzels, Jacob W. and Mihalyi Czikszentmihalyi. The Creative Vision: A Longitudinal Study of Problem Finding in Art. New York: Wiley, 1976. Print.

Ghosh, Shubha and Robin Paul Malloy. Creativity, Law and Entrepreneurship. Cheltenham, UK: Edward Elgar, 2011. Print.

Grant, Daniel. The Business of Being an Artist. Allworth Press: New York, 2010. Print.

Grichnik, Dietmar et al. "Beyond Environmental Scarcity: Human and Social Capital as driving forces of Bootstrapping Activities.” Journal of Business Venturing. 29(2014):310-326. Print.

Grodach, C. "Art Spaces in Community and Economic Development: Connections to Neighborhoods, Artists, and the Cultural Economy." Journal of Planning Education and Research 31.1 (2010): 74-85. Sage Publication. Web. 14 July 2016.

Guildford, J.P. "Creative Abilities in the Arts." Psychological Review.64.110119(1957):112-114. APA PsycNet. Web. 14 July 2016.

Hammersley, Martin. What is Qualitative Research? Bloomsbury: London, 2013. Print.

Henry, Colette. Entrepreneurship in the Creative Industries: An International Perspective. Edward Elger: Cheltenham, 2007.Print.

Hill Strategies. "A Statistical Profile of Artists and Cultural Workers in Canada." National Household Survey 2011. Hill Research Strategies. Statistics Canada, 7 October, 2014.Web.14 July 2016. http://www.hillstrategies.com/content/statistical-profile-artistsand-cultural-workers-canada

Holbrook, Morris B. "Some Preliminary Notes on Consumer Esthetics." Advances in Consumer Research.7(1980)104-108.Print.

Horowitz, Andrew. "Artist as Entrepreneur: The American Model or Same Old American Dream?" The Guardian. 5. Dec. 2013.Web. 12 June 2016.

Horowitz, Ben. The Hard Thing about Hard Things: Building a Business When There Are No Easy Answers. Harpers Collins: New York, 2014. Print.

Howkins, John. The Creative Economy: How People Make Money from Ideas. London: Penguin, 2002. Print.

Howkins, John, Anne Markusenn, and Anne Gadwa Nicodemus. Creative Industries. Prague: Aspen Review, 2015. Print.

Isaacson, Walter. Steve Jobs. Simon \&Schuster: New York, 2013. Print. 
Izquierdo, Carmen Camarero, and Maria Jose Garrido Samaniego. "How Alternative Marketing Strategies Impact the Performance of Spanish Museum. ” Journal of Management Development. 26.9 (2007):809-831. Emerald Insights. Web. 13 June 2016.

Jackson, Ronald L, Darlene K Drummond, and Sakile Camara. "What is Qualitative Research" Qualitative Research Report in Communication. 8.1(2007).21-28. Taylor and Francis. Web. 21 August 2016.

Jaussi, K.S, Amy E. Ranfel, and Shelley Dionne. "I am, I Think I Can, and I Do: The Role of Personal Identity, Self Efficacy, and Cross-Application of experiences in Creativity at Work." Creativity Research Journal.19(2007):247-258.ResearchGate. Web. 23 June 2016.

Kahn, M. “An Introduction to Arts Incubators." National Association of Local Arts Agencies Monographs, 4.3(1995):1-16. Print.

Kasfir, Sidney Littlefield. "Artists' Reputations: Negotiating Power through Separation and Ambiguity." African Arts 33.1 (2000): 70. Web.

Kester, Grant. Conversation Pieces: Community and Communication in Modern Art. Berkeley: University of California Press, 2004. Print.

King, L.A., Walker, L.M., and Broyles, S.J. "Creativity and the Five Factor Model." Journal of Research in Personality. 30. (1996). 189-203.Print.

Kaufman, James C. Creativity 101. New York, NY: Springer Pub., 2009. Print.

Kumar, Nirmalya, Lisa Scheer, and Philip Kotler. "From Market Driven to Market Driving” European Management Journal 18.2 (2000).129-142.Print.

Kreuger, Norris F., Michael D Reilly, and Alan L. Carsrud. "Competing Models of Entrepreneurial Intentions.” Journal of Business Venturing.15 (2000) 411-432.Print.

Leutner, Franziska et al. "The Relationship between the Entrepreneurial Personality and the Big Five Personality Traits" Personality and Individual Differences. 63(2014):58-63. Elsevier. Web. 12 February 2016.

Lin, Nan. "Building and Network Theory of Social Capital." Connections 22(1999).2851.ISNA. Web.14 July 2016.

Livingston, Jessica. Founders at Work: Stories of Startups Early Days. Apress: New York, 2008. Print.

MaRS Discover District Website. MaRS Discover District. https://www.marsdd.com/. Accessed 04 Aug 2016. 
Mayer, Catherine. "Damien Hirst: 'What Have I Done? I've Created a Monster.'” The Guardian, June 30, 2015, n.pag.

McCrae, R.R. "Creativity, Divergent Thinking and Openness to Experience.” Journal of Personality and Social Psychology.52(1987).1258-1265.Print.

Meyers, Herbert, and Richard Gerstman. Creativity: Unconventional Wisdom from 20 Accomplished Minds. Basingstoke: Palgrave Macmillan, 2007. Print.

Mill. J.S. Principles of Political Economy with Some applications to Social Philosophy. London: John W.Parker, 1984. Print.

Moulard, Juile Guidry et al. "Artist Authenticity: How Artists' Passion and Commitment Shape Consumer's Perception and Behavioural Intentions Across Genders." Psychology \&Marketing. 31.8 (2014):576-590. Wiley Online.Web. 14 July 2016.

Mueller, Jessica, Florian B. Zapkau, and Christian Schwens. "Impact of Prior Entrepreneurial Exposure on Entrepreneurial Intention-Cross Cultural Evidence.” Journal of Enterprising Culture.22.3:(2014) 251-282. Print.

Nieves, M. Taking Aim!: The Business of Being An Artist Today. Fordham UP: New York, 2011. Print.

Oakley, Kate and Leadbeater, Charles. The Independents: Britain's New Cultural Entrepreneur. Demos: London, 1999. Print.

Oakley, Kate. "The Disappearing Arts: Creativity and Innovation After the Creative Industries.” International Journal of Cultural Policy. 15.4 (2009):403-413.

ResearchGate. Web. 23 March 2016.

O’Connor, Justin. “Creative Industries: A New Direction.” International Journal of Cultural Policy. 15.4(2009)387-402.Taylor and Francis. Web. 23 March 2016.

O'Connor, Justin and Banks, Mark. "After the Creative Industries." International Journal of Cultural Policy. 15.4(2009):365-373. Taylor and Francis. Web. 23 March 2016.

Olesiewicz, Konrad. "Artistic Entrepreneurship and the Need for Market Orientation in the Context of Rising Significance of the Creative Industries." SSRN Electronic Journal SSRN Journal.1.1(2011):1-20. ResearchGate.Web.05 Jan 2016.

Ontario Ministry of Tourism. “Ontario's Entertainment \& Creative Cluster Report: A Framework for Growth." Ministry of Tourism and Culture. Government of Ontario, 2010. Web. 12 Feb 2016.

Parkman, Ian D, Samuel S Holloway, and Helder Sebastiao. "Creative Industries: Aligning Entrepreneurial Orientation and Innovation Capacity." Journal of Research in 
Marketing and Entrepreneurship. 14.1 (2012): 95-114. ResearchGate.Web. 24 January 2016.

Patz. Mathias .Lean Startup-Adding an Experimental Learning Perspective to the Entrepreneurial Process. MS. Thesis. University of Twente, 2013.Print.

Phillips, Rhonda. "An Introduction to Arts Incubators." National Association of Local Arts Agencies Monographs.1.1(2013):1-16. Creative Infrastructure. Web. 23 March 2016.

Potts, Jason. Creative Industries and Economic Evolution. Cheltenham: Edward Elgar Pub, 2013. Print.

Potts, Jason and Cunningham, Stuart. "Four Models of the Creative Industries" International Journal of Cultural Policy.14.3(2008):233-247.Print.

Potts, James et al. "Social Network Markets: A New Definition of the Creative Industries." Journal of Cultural Economics:32(2008). 167-185. Web.

Pratt, A.C. "Creative Clusters: Towards the Governance of Creative Industries Production System?" Media International Australia Incorporating Culture and Policy. 112(2004).50-66. Sage. Web. 23 March 2016.

Ries. Eric. Lean Startup: How Today's Entrepreneurs Use Continuous Innovation to Create Radically Successful Business. Crown: New York,2011. Print.

Runco, Mark A., Jonathan A. Plucker, and Lim Woong."Development and Psychometric Integrity of a Measure of Ideational Behaviour." Creativity Research Journal.13(20002001):393-400.Print.

Sandelowski, Margaret. "Using Qualitative Research.” Qualitative Health Research. 14.10(2004):1366- 1386. Print.

Sawyer, R. Keith. Explaining Creativity: The Science of Human Innovation. Oxford: Oxford UP, 2006. Print.

Shannon, Claude and Weaver, Warren. The Mathematical Theory of Communication. University of Illinois Press; Chicago, 1949. Print.

Schiuma, Giovanni. The Value of Arts for Business. Cambridge: Cambridge UP, 2011. Print.

Schumpeter, Jospeh Alois and Ursula Backhaus. "The Theory of Economic Development." The European Heritage in Economics and the Social Sciences.1.1(2003):61-116. Springer. Web. 14 July 2016. 
Shapero, Albert and Sokol, Lisa. "Social Dimensions of Entrepreneurship." The Encyclopedia of Entrepreneurship. Edited by C Kent, D. Sexton, and K.Vesper. Englewood Cliffs: Prentice Hall, 1982, pp. 72-90.

Shorthose , Jim and Strange, Gerard. "The New Cultural Economy, the Artist and The Social Configuration of Autonomy." Capital and Class. 84(2015):740-754.SAGE. Web.04 Aug 2016.

Silvia, Paul J., Christopher Martin and Emily C. Nusbaum. "A Snapshot of Creativity: Evaluating a Quick And Simple Method for Assessing Divergent Thinking.” Thinking Skills \&Creativity.4(2009):79-85. Elsevier. Web. 04 June 2016.

Swedberg, Richard. "The Cultural Entrepreneur and the Creative Industries: Beginning in Vienna." Journal of Cultural Economy.30(2006). 243-261. Print.

Taylor, Astra. The People's Platform: Taking Back Power and Culture in the Digital Age. Toronto: Random House, 2014.

Thorsby, David. "The Production and Consumption of the Arts: A View on Cultural Economics." Journal of Economic Literature.32.1(1994):1-29. Print.

Throsby,David. Economics and Culture. Cambridge UP: Cambridge, 2001. Print.

Throsby,David . "An Artistic Production Function: Theory and Application to Australian Visual Arts" Journal of Cultural Economics. 30 (2006):1-14. Print.

Tierney, Pamela, and Farmer, Steven. "Creative Self-Efficacy: Its Potential Antecedent and Relationship to Creative Performance." Academy of Management Journal, 45.6(2002):1137-1148.ResearchGate. Web. 14 July 2016.

Timberg, Scott. Culture Crash: The Killing of the Creative Class. New Haven: Yale UP: 2015. Print.

Timmons, J.A. The Entrepreneurial Mind. Andover, Mass: Brick House Pub Co, 1989. Print.

Ward, T.B. "Cognition, Creativity and Entrepreneurship." Journal of Business Venturing. 19 (2004):173-188. Print.

Win, Thet Shein. "Marketing the Entrepreneurial Artist in the Innovation Age: Aesthetic Labor, Artistic Subjectivity, and the Creative Industries." Anthropology of Work Review. 35.1(2014).1-13. Wiley. Web.23 March 2016.

Winborg, Joakim and Landstrom,Hans. "Financial Bootstrapping in Small Business: Examining Small Business Manager's Resource Acquisition Behaviours. "Journal of Business Venturing. 16.3.(2001):235-254.Elsiever. Web.20 January 2016. 